\title{
A prospective randomized trial of two popular mononuclear cell collection sets for autologous peripheral blood stem cell collection in multiple myeloma
}

\author{
Laura Cooling, Sandra Hoffmann, Michelle Herrst, Charles Muck, Heidi Armelagos, and \\ Robertson Davenport
}

BACKGROUND: The COBE Spectra AutoPBSC collection set (AUTO-kit; CaridianBCT) is a popular dualstage collection set for peripheral blood progenitor (PBPC) collection. Although the AUTO-kit is purportedly equivalent to the white blood cell (WBC) collection set (WBC-kit) for PBPC collection, improved CD34 yields after switching from the AUTO-kit to the WBC-kit were anecdotally observed, particularly in patients with higher WBC counts. A prospective, randomized trial of the AUTO- and WBC-kits for PBPC collection in multiple myeloma (MM) patients was therefore designed. STUDY DESIGN AND METHODS: Sixty-eight MM patients were prospectively randomly assigned to either the WBC-kit or the AUTO-kit for PBPC collection. Primary study variables included the number of leukapheresis procedures per transplant, CD34/kg yield per procedure, and cumulative CD34/kg yield per mobilization cycle. Results were compared relative to collection kit and mobilization regimen. Statistics and graphics were performed with commercial software.

RESULTS: CD34/kg yields were higher with the WBCkit, with $94 \%$ of chemotherapy-mobilized MM patients collecting 6 million CD34/kg in a single mobilization $(p=0.06)$. The WBC-kit also had a faster CD34 collection rate relative to peripheral CD34 counts. The AUTOkit was significantly sensitive to high WBC counts, with a 50\% decrease in CD34 collection efficiency and CD34 collection rate. This effect was specific to MM and not observed in lymphoma patients. Granulocytecolony-stimulating factor mobilization and the AUTO-kit were associated with an increased incidence and severity of infusion reactions.

CONCLUSIONS: The WBC-kit performed consistently better than the AUTO-kit for PBPC collection in chemotherapy-mobilized MM patients, with fewer procedures per mobilization, superior collection rates, and a decreased incidence of infusion reactions.

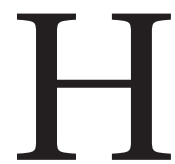
igh-dose chemotherapy, followed by autologous peripheral blood progenitor cell transplantation (APBPCT), has become an accepted treatment for many hematologic malignancies, including multiple myeloma (MM)., ${ }^{1,2}$ Although not curative, APBPCT can double disease-free survival in MM, with $40 \%$ of patients surviving 7 years in some studies. ${ }^{2,3}$ More recent strategies to improve long-term survival include retransplantation, ${ }^{4,5}$ planned tandem APBPCT, ${ }^{6-8}$ allogeneic transplantation, ${ }^{9}$ and posttransplant therapy with thalidomide. ${ }^{10,11} \mathrm{MM}$ is now the most common indication for APBPCT, ${ }^{12}$ with many transplant centers requiring the collection of 6 to 20 million CD34 $/ \mathrm{kg}$, or sufficient cells to support two to three APBPCTs. ${ }^{11,13,14}$ At the University of Michigan, MM patients now comprise $52 \%$ of all patients and $54 \%$ of all PBPC collections.

ABBREVIATIONS: APBPCT(s) = autologous PBPC transplant(s); AUTO-kit $=$ AutoPBSC collection set CBC $=$ complete blood count; $\mathrm{CE}$ = collection efficiency; chemo + GF = chemotherapy and growth factor mobilization; DT-PACE $=10 \mathrm{mg} / \mathrm{m}^{2}$ cisplatin, $10 \mathrm{mg} / \mathrm{m}^{2}$ doxorubicin, $400 \mathrm{mg} / \mathrm{m}^{2}$ cyclophosphamide, $40 \mathrm{mg} / \mathrm{m}^{2}$ etoposide, $40 \mathrm{mg}$ oral dexamethasone, $200 \mathrm{mg}$ thalidomide; GF-only = growth factor only mobilization; $\mathrm{MM}=$ multiple myeloma; NHL = non-Hodgkin's lymphoma; $\mathrm{TBV}(\mathrm{s})=$ total blood volume $(\mathrm{s})$; WBC-kit $=$ WBC collection set .

From the Department of Pathology, University of Michigan Hospitals, Ann Arbor, Michigan.

Address reprint requests to: Laura Cooling, MD, MS, Pathology, Associate Medical Director, Transfusion Medicine, University of Michigan Hospitals, 2F225 UH, Box 0054, 1500 E. Medical Center Drive, Ann Arbor, MI 48109-0054; e-mail: lcooling@med.umich.edu.

Received for publication March 5, 2009; revision received June 9, 2009, and accepted June 10, 2009.

doi: 10.1111/j.1537-2995.2009.02350.x

TRANSFUSION 2010;50:100-119. 
The rising clinical demand for leukopheresis services has stimulated intense interest in identifying patient, treatment, and technical factors that will improve PBPC mobilization and collection. Factors favoring mobilization are a diagnosis of $\mathrm{MM},{ }^{15,16}$ mobilization with chemotherapy, ${ }^{17-20}$ growth factor dose, ${ }^{13,16,19,21}$ the premobilization platelet (PLT) count, ${ }^{17,22,23}$ and peripheral blood counts (white blood cells [WBCs], CD34 $>20 / \mu$ L, PLTs) at the time of leukapheresis. ${ }^{24-26}$ Poor prognostic factors are an older age, female sex, a diagnosis of non-Hodgkin's lymphoma (NHL), extensive prior chemotherapy, and a history of radiation therapy. ${ }^{17,18,27}$ Although frequently overlooked, procedure-related factors can also impact collection. These include patient vascular access and flow rate, ${ }^{28-31}$ total blood volume (TBV) processed, ${ }^{15,27}$ operator experience, and the specific apheresis device used. ${ }^{24,32-44}$

At the University of Michigan, we have historically used the COBE Spectra blood separator (CaridianBCT, Lakewood, CO) with the AutoPBSC collection set (AUTOkit) and automated mononuclear cell (MNC) software (Version 6.1) for adult collections. The latter is a fully automated program and dual-stage collection set that requires minimal operator intervention, decreased citrate toxicity, less PLT contamination, and reportedly, equivalent or superior collection efficiencies (CEs) to other collection platforms. ${ }^{40-44}$ In 2005, we noted an increase in the number of leukapheresis procedures required for APBPCT, particularly in MM patients with high peripheral WBC counts. In many of these patients, we anecdotally observed improved CD34 collection yields after switching to the WBC collection set (WBC-kit). We therefore designed a prospective randomized trial comparing the performance of the AUTO-kit and WBC-kit in MM patients. We demonstrate that the WBC-kit and chemotherapy mobilization resulted in higher CD34 collection yields, fewer total procedures, and decreased infusion toxicity.

\section{MATERIALS AND METHODS}

\section{Patient criteria}

All adult MM patients referred for autologous PBPC collection between December 2005 and July 2007 were enrolled. All patients were evaluated and medically cleared for APBPCT according to institutional guidelines before their first leukapheresis procedure. The target yield for all MM patients was $6 \times 10^{6} \mathrm{CD} 34$ cells $/ \mathrm{kg}$ or two APBPCTs $\left(3 \times 10^{6} / \mathrm{kg}\right.$ per transplant). Informed consent for leukapheresis and infectious disease testing was obtained from all patients on the first day of collection. All protocols and consent for PBPC mobilization, collection, and transplantation, including this study, were approved by the institutional review board of the University of Michigan.

\section{Study design}

Patients were alternately assigned to either the WBC-kit or AUTO-kit on the first day of apheresis, and all subsequent collections, until the designated target yield of $6 \times 10^{6}$ CD34 $/ \mathrm{kg}$ was achieved. ${ }^{42}$ During the course of the study, eight patients were randomly assigned to the incorrect group (six to AUTO, two to WBC). Ten patients with poor collection yields $\left(<0.5 \times 10^{6} \mathrm{CD} 34 / \mathrm{kg} /\right.$ day; $\left.\mathrm{CD} 34 / \mu \mathrm{L}>20\right)$ on 2 successive days were switched to the alternate collection kit at the discretion of the apheresis attending physician ("Mixed," Fig. 1). Patients failing to collect $6 \times 10^{6}$ CD34 cells were remobilized and collected at a later date. In remobilized patients, each mobilization cycle was considered a separate event for postcollection analysis. Only patients collecting at least $3 \times 10^{6} \mathrm{CD} 34 / \mathrm{kg}$ in a single mobilization cycle were included in postcollection analysis: Mobilization cycles collecting less than $3 \times 10^{6}$

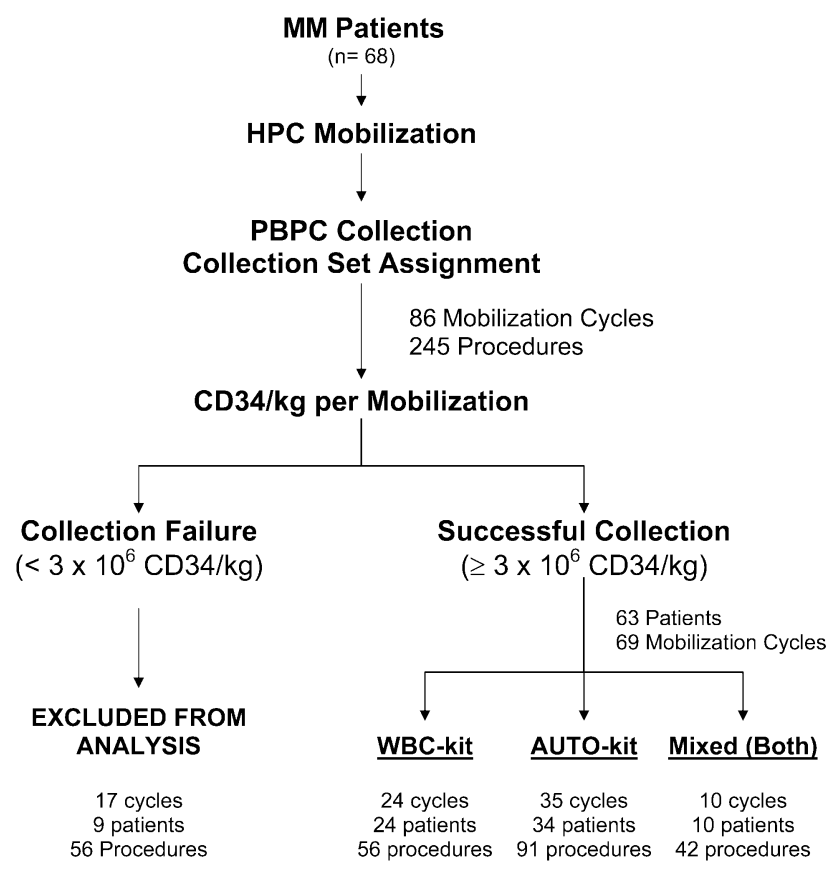

Fig. 1. Study schematic. Sixty-eight MM patients were randomly assigned to either the WBC-kit or AUTO-kit. Each mobilization cycle was considered a separate event for analysis. Altogether, 69 cycles from 63 patients successfully collected at least $3 \times 10^{6} \mathrm{CD} 34 / \mathrm{kg}$ in a single mobilization. Seventeen cycles were excluded from analysis due to poor collection yields. 63 cycles represent a primary mobilization. Six patients were remobilized to collect sufficient cells for a second APBPCT. All successful mobilizations, including remobilizations, were categorized in postcollection analysis by collection kit used: AUTO-kit, WBC-kit, and mixed, in which both AUTO- and WBC-kits were used during the course of a single mobilization. Most remobilized patients (five of six) were collected in a different treatment arm for the first and second mobilization. 


\begin{tabular}{|lc|}
\hline \multicolumn{2}{|c|}{ TABLE 1. Excluded mobilization cycles } \\
\hline Patient characteristics & Number $(\%)$ \\
\hline Number of patients $(\%)$ & 9 \\
Age (years), mean \pm SD & $56.7 \pm 6.8$ \\
Male/female & $6 / 3$ \\
IgG/lgA & $7 / 1$ \\
Peripheral blood counts, mean \pm SD & \\
WBCs $\left(\times 10^{\%} / L\right)$ & $26.5 \pm 15.9$ \\
CD34/ $\mu$ L & $19.5 \pm 15.0$ \\
Prior therapy $(\%)$ & \\
Radiation & $3(30)$ \\
$\geq 5$ courses anthracyclines & $5(55)$ \\
$\geq 3$ courses alkylating agents & $4(30)$ \\
Second-line therapy & $4(44)$ \\
Prior APBPCT & $1(11)$ \\
Other cancer & $1(11)$ \\
$>70$ years of age & 0 \\
$>6$ months of lenolamide & 0 \\
PBPC collection $($ AUTO-kit/WBC-kit) & \\
Total number of procedures & $56(25 / 31)$ \\
Total mobilizations & $17(9 / 8)$ \\
First mobilization & $7(3 / 4)$ \\
Remobilization & $10(6 / 4)$ \\
GF-only mobilization $(\%)$ & $12(70)$ \\
CD34/kg yield $\left(\times 10^{6}\right)$, mean \pm SD & \\
Per procedure & $0.45 \pm 0.27$ \\
Per cycle & $1.49 \pm 0.77$ \\
& \\
&
\end{tabular}

CD34/kg were excluded. A total of 17 mobilization cycles, involving nine patients and 57 procedures, were excluded due to poor collection yields (Fig. 1, Table 1).

Patient demographic data included patient age, sex, weight, MM subtype, CD34 mobilization regimen, and number of mobilization cycles (Table 2). Patient laboratory studies included baseline and Day 1 preapheresis complete blood count (CBC), manual WBC differential, peripheral CD34 count (\%CD34, CD34/ $\mu \mathrm{L})$, and total protein and albumin. A daily preapheresis $\mathrm{CBC}$ and WBC differential were recorded for all patients requiring more than one procedure. When available, preapheresis quantitative serum immunoglobulin and whole blood viscosity were recorded. Procedure-related data included collection kit (AUTO, WBC), nurse operator, TBV, TBV per body weight $(100 \mathrm{~mL} / \mathrm{kg})$, cumulative $\mathrm{CD} 34 / \mathrm{kg}$ yield, and number of procedures per mobilization cycle (Table 3 ). TBV was not corrected for anticoagulant volume.

\section{Mobilization regimens}

CD34 mobilization was determined by the patient's attending transplant physician. The majority of patients $(70 \%$, Table 2$)$ enrolled were collected after chemotherapy, followed by daily granulocyte-colony-stimulating factor (G-CSF; $10 \mu \mathrm{g} / \mathrm{kg} /$ day). For chemotherapy, patients were treated with either cyclophosphamide $\left(2-4 \mathrm{~g} / \mathrm{m}^{2}\right)$ or DT-PACE $\left(10 \mathrm{mg} / \mathrm{m}^{2}\right.$ cisplatin, $10 \mathrm{mg} / \mathrm{m}^{2}$ doxorubicin, $400 \mathrm{mg} / \mathrm{m}^{2}$ cyclophosphamide, $40 \mathrm{mg} / \mathrm{m}^{2}$ etoposide, $40 \mathrm{mg}$ oral dexamethasone, $200 \mathrm{mg}$ thalidomide)..$^{14,45,46}$
Leukapheresis was initiated between 11 and 14 days after chemotherapy when the peripheral WBC count exceeded $5.0 \times 10^{9} / \mathrm{L}^{34,47}$ Patients collected after chemotherapy, regardless of specific chemotherapy regimen, were classified as "chemotherapy + growth factor" mobilization (chemo + GF; Table 2) for subsequent analysis.

Approximately $30 \%$ of patients were mobilized with G-CSF only (10-16 $\mu \mathrm{g} / \mathrm{kg} /$ day), starting 4 days before the first leukapheresis procedure (Table 2). A minority of these patients were mobilized with G-CSF $(10 \mu \mathrm{g} / \mathrm{kg})$ and granulocyte-macrophage-CSF (GM-CSF; $500 \mu \mathrm{g} /$ day). Patients mobilized with either G-CSF or G-CSF plus GM-CSF were classified as "growth factor only" (GF-only) for purposes of analysis.

\section{Apheresis collections}

All leukapheresis procedures were performed on a COBE Spectra blood separator. Venous access was established using a central venous catheter. For patients randomly assigned to the WBC-kit (Software Version 4.7), MNCs were collected by continuous-flow centrifugation, with the blood-plasma interface manually adjusted to a $1 \%$ to $2 \%$ hematocrit (Hct) using a WBC colorgram (COBE Spectra), a maximum flow rate of $80 \mathrm{~mL} / \mathrm{min}$, a whole blood:ACDA ratio of 12:1, and collect volume rate of $1.0 \mathrm{~mL}$ per minute. For the AUTO-kit, MNCs were collected using the manufacturer's default software settings (Version 6.1). Harvest volume $(5.0 \mathrm{~mL})$, chase volume $(5.0 \mathrm{~mL})$, whole blood flow rates, and harvest frequency were determined by the system based on patient size, MNC concentration, and inlet flow rate. ${ }^{42}$ Approximately $200 \mathrm{~mL}$ of PLT-depleted plasma was collected concurrently. For AUTO- and WBC-kits, three TBVs were processed, averaging $13 \mathrm{~L}$ or $162 \mathrm{~mL} / \mathrm{kg}$ per procedure (Table 3). To prevent citrate toxicity, all patients received prophylactic calcium gluconate replacement throughout the procedure. ${ }^{48}$

\section{PLT analysis}

The impact of leukapheresis on peripheral PLT counts was monitored by daily preapheresis PLT counts. The transfusion records for all patients were also reviewed for any PLT or RBC transfusion support during the week of PBPC collection.

\section{Product analysis}

Volume and WBC count were determined on all products immediately after collection. For units requiring volume reduction, the initial and final volume, WBC count, and percentage of cell loss were recorded (Table 2). The final $\% \mathrm{MNC}$ and $\mathrm{MNCs} / \mathrm{kg}$ were determined on all products before freezing. CD34 yields and cell viability were 


\begin{tabular}{|c|c|c|c|c|}
\hline \multirow[b]{2}{*}{ Measure } & \multirow[b]{2}{*}{ All collections* } & \multicolumn{3}{|c|}{ PBPC collection set† } \\
\hline & & WBC-kit & AUTO-kit & $\mathrm{p}$ Value \\
\hline \multicolumn{5}{|l|}{ Peripheral blood counts $\ddagger$} \\
\hline WBCs count $\left(\times 10^{9} / \mathrm{L}\right)$ & $31.3 \pm 19.9$ & $28.1 \pm 17.7$ & $29.2 \pm 18.4$ & NS \\
\hline WBCs, Day 1 & $26.6 \pm 21.8$ & $25.7 \pm 19.3$ & $23.7 \pm 17.4$ & NS \\
\hline$\%$ MNCs & $14.8 \pm 13.5$ & $12.4 \pm 7.3$ & $12.4 \pm 11.5$ & NS \\
\hline$\% \mathrm{Hct}$ & $31.5 \pm 4.9$ & $30.6 \pm 4.9$ & $31.9 \pm 4.4$ & NS \\
\hline Hct, Day 1 & $32.5 \pm 5.1$ & $32.4 \pm 4.7$ & $32.1 \pm 4.6$ & NS \\
\hline PLT count $\left(\times 10^{9} / \mathrm{L}\right)$ & $140.7 \pm 81.9$ & $127.7 \pm 71.8$ & $131.0 \pm 73.9$ & NS \\
\hline PLTs, Day 1 & $157.6 \pm 103.8$ & $146.7 \pm 94.5$ & $145.9 \pm 92.1$ & NS \\
\hline PLT count $>200\left(\times 10^{\%} / L\right)$, Day $1(\%) \S$ & 20/69 (29) & $6 / 24(25)$ & 9/34 (26) & NS \\
\hline \%CD34, Day 1 (range) & $0.62 \pm 0.88(0.02-4.68)$ & $0.65 \pm 0.62(0.04-2.38)$ & $0.81 \pm 1.00(0.05-4.68)$ & NS \\
\hline CD34/ $\mu \mathrm{L}$, Day 1 & $125.2 \pm 184.2$ & $153.2 \pm 200.5$ & $142.3 \pm 193.3$ & NS \\
\hline Median (range) & $56(0.16-80.0)$ & $70.3(3.4-800)$ & $64.2(3.7-777)$ & \\
\hline \multicolumn{5}{|l|}{ Collection } \\
\hline Total number of procedures & 189 & 57 & 91 & - \\
\hline Procedures per mobilization & $2.8 \pm 1.5$ & $2.3 \pm 1.3$ & $2.6 \pm 1.4$ & NS \\
\hline TBV processed (L) & $13.7 \pm 3.6$ & $13.3 \pm 3.4$ & $13.5 \pm 3.6$ & NS \\
\hline TBV $(100 \mathrm{~mL}) / \mathrm{kg}$ & $161.8 \pm 31.8$ & $169.8 \pm 35.2$ & $160.8 \pm 31.5$ & NS \\
\hline $\begin{array}{l}\text { Percentage decrease in PLT count } \\
\text { per day } \text { (range) }\end{array}$ & $12.5 \pm 13.6(0-53)$ & $13.3 \pm 15.5(0-43)$ & $10.5 \pm 10.9(0-46)$ & NS \\
\hline Number of PLT transfusions ${ }^{\star *}$ & 1 & 1 & 0 & NS \\
\hline Number of RBC transfusions** & 0 & 0 & 0 & NS \\
\hline \multicolumn{5}{|l|}{ Product characteristics } \\
\hline \multicolumn{5}{|l|}{ Volume (mL) } \\
\hline Initial volume & $145.1 \pm 82.0$ & $180.9 \pm 75.1$ & $111.6 \pm 70.4$ & $<0.0001$ \\
\hline Final volume & $102.1 \pm 37.1$ & $99.5 \pm 37.4$ & $93.8 \pm 33.3$ & NS \\
\hline Number of units processed (\%) & $110(58)$ & $44(77)$ & $41(45)$ & 0.0006 \\
\hline \multicolumn{5}{|l|}{ WBCs $\left(\times 10^{9} / \mathrm{L}\right)$} \\
\hline Initial WBC count (range) & $\begin{array}{l}255.6 \pm 887.8 \\
(15.8-943.7)\end{array}$ & $\begin{array}{l}340.5 \pm 1405 \\
(15.8-943.7)\end{array}$ & $\begin{array}{c}207.1 \pm 83.4 \\
(53.5-315.5)\end{array}$ & NS \\
\hline Final WBC count (range) & $\begin{array}{l}246.9 \pm 95.6 \\
(27-684)\end{array}$ & $\begin{array}{l}233.1 \pm 104.5 \\
(27-547.8)\end{array}$ & $\begin{array}{l}246.5 \pm 86.7 \\
(77.1-684)\end{array}$ & NS \\
\hline Number of units with cell loss & $58 / 110$ & $22 / 44$ & $23 / 41$ & NS \\
\hline Median cell loss & $5 \%$ & $5 \%$ & $4 \%$ & NS \\
\hline Total MNC yield $\left(\times 10^{10}\right)$ & $1.41 \pm 0.87$ & $1.48 \pm 0.92$ & $1.36 \pm 0.84$ & NS \\
\hline$\%$ MNCs & $56.3 \pm 21.4$ & $59.3 \pm 25.1$ & $54.5 \pm 18.6$ & NS \\
\hline$\% M N C-C E$ & $39.4 \pm 20.6$ & $40.4 \pm 16.2$ & $38.7 \pm 18.9$ & NS \\
\hline \%CD34 (range) & $1.25 \pm 2.10(0.04-22.23)$ & $1.60 \pm 1.75(0.1-8.3)$ & $1.42 \pm 2.62(0.4-22.23)$ & NS \\
\hline$\%$ CD34-CE & $32.6 \pm 31.4$ & $31.3 \pm 19$ & $33.6 \pm 37.0$ & NS \\
\hline \multicolumn{5}{|l|}{ Collection yields $/ \mathrm{kg}$} \\
\hline MNCs/kg per unit $\left(\times 10^{8}\right)$ & $1.61 \pm 0.88$ & $1.66 \pm 0.94$ & $1.55 \pm 0.83$ & NS \\
\hline CD34/kg per unit $\left(\times 10^{6}\right)$ (range) & $3.25 \pm 5.19(0.1-41.2)$ & $4.67 \pm 7.11(0.3-41.2)$ & $3.26 \pm 4.67(0.1-33.4)$ & NS \\
\hline CD34/kg per mobilization & $9.54 \pm 7.08$ & $11.08 \pm 8.67$ & $8.48 \pm 5.63$ & 0.048 \\
\hline \multicolumn{5}{|c|}{$\begin{array}{l}\text { * All collections regardless of collection kit, including mixed collections. Most results reported as mean } \pm \text { SD unless otherwise indicated. } \\
\dagger \text { Comparison (t test) of WBC-kit and AUTO-kit: mixed collections not included. } \\
\ddagger \text { Mean preleukapheresis peripheral blood count for all procedures. Blood counts before the first procedure (Day } 1) \text { also included. } \\
\S \text { Number and percentage of patients with a PLT count of more than } 200 \times 10^{9} / \mathrm{L} \text { on the first day of leukapheresis. }{ }^{23} \text { PLT counts of greater } \\
\text { than } 200 \times 10^{9} / \mathrm{L} \text { were strongly associated with GF-only mobilization }(14 / 20 ; p=0.00005) \text {. } \\
\text { I Mean percentage change in daily PLT count per procedure. } \\
* * \text { Number of patients requiring either PLT or RBC transfusion during leukapheresis. Only one patient required a PLT transfusion the day } \\
\text { before starting PBPC collection for a PLT count of } 12 \times 10^{\circ} / \mathrm{L} \text {. } \\
\text { NS = not significant. }\end{array}$} \\
\hline
\end{tabular}

in MM patients were restricted to patients collected solely with the AUTO- or WBC-kit for the entire mobilization cycle: "mixed" collections were excluded. Mixed collections were only included in the aggregate data of all collections.

Patient demographic, laboratory, and collection results were reported as the mean \pm standard deviation (SD), percentage, median, and range as indicated. The MNC and CD34 CEs (\%CE) were calculated as described by Dzieczkowski and coworkers ${ }^{33}$ and Ford and coworkers, ${ }^{31}$ respectively. Categorical variables were compared prima- rily by t test unless otherwise indicated. Proportional variables were examined by chi-square (EpiInform, CDC, Atlanta, GA). To determine the significance of individual CD34 collection rates (slope, b), the confidence interval (CI) for each slope was calculated using the appropriate critical $t$ values $\left(t^{*}\right)$ at $t(n-2)$ distribution, where

$$
\mathrm{CI}=\mathrm{b} \pm \mathrm{b}_{\mathrm{SE}}\left(\mathrm{t}^{*}\right) .^{50}
$$

Univariate statistics ( $\mathrm{t}$ test, paired t test, Mann-Whitney U test), correlation coefficient (R), correlation probabilities, 
linear regression including t-probabilities and standard error, and graphics were performed with commercial software (Kaleidograph, Synergy Software, Reading, PA). A p value of less than 0.05 was considered significant.

\section{RESULTS}

\section{Patient demographics}

Between December 2005 and July 2007, a total of 68 MM patients underwent autologous PBPC collection at our facility. Sixty-three patients (93\%), who successfully collected at least $3 \times 10^{6} \mathrm{CD} 34$ cells $/ \mathrm{kg}$ in a single mobilization, were included in the final analysis. Six patients required a second mobilization to reach $6 \times 10^{6} \mathrm{CD} 34 / \mathrm{kg}$ or two APBPCTs. Altogether, 69 mobilization cycles and 189 procedures were available for analysis.

Seventeen mobilizations were excluded from the final analysis, including 14 cycles from six patients with multiple poor mobilizations and three cycles from three patients who had one prior successful collection but failed to remobilize after additional chemotherapy and GF-only mobilization (Fig. 1). Excluded cycles were associated with GF-only mobilization $(\mathrm{p}=0.002)$, low $\mathrm{CD} 34 / \mu \mathrm{L}$ $(\mathrm{p}<0.0001)$, and poor CD34/kg yields $(\mathrm{p}<0.001)$. Many patients had risk factors for poor mobilization including prior radiotherapy and extensive chemotherapy (Table 1). ${ }^{17,18,27}$

For analysis, each successful collection was classified by the type of kit used, WBC-kit or AUTO-kit, during the entire mobilization collection cycle. Mixed collections, in which patients were switched to the alternate collection set, were only included in the aggregate data of all collections (All), regardless of collection set. As shown in Tables 2 and 3, there was no significant difference in patient age, sex, weight, or TBV processed between collection kits. Approximately $70 \%$ of all patients, regardless of kit, were collected after chemotherapy (chemo + GF) while the remaining $30 \%$ were mobilized with GF-only. The AUTO-kit group had a higher percentage of patients mobilized with DT-PACE (52\%), which we have shown to be equivalent to cyclophosphamide for PBPC mobilization in MM. ${ }^{46}$

\section{Peripheral blood counts}

The CBC, \%MNCs, and CD34 counts on the first day of collection, and for all procedures in aggregate, were compared by kit (Table 3) and mobilization regimen (Table 4). There was no significant difference in peripheral WBC, \%MNC, \%Hct, and PLT and CD34 counts between kits, although AUTO-kit patients had a higher mean \%CD34 (Table 3). Patients mobilized with GF-only had a higher mean WBC count whereas chemo + GF patients had significantly higher peripheral CD34 counts (Table 4).

\section{Product characteristics}

PBPC products collected with the WBC-kit had a greater initial volume and $\mathrm{WBC}$ count, on average, than the AUTO-kit (Table 3). ${ }^{40-43}$ Volume reduction was performed on $45 \%$ of AUTO-kit and $77 \%$ of WBC-kit products before freezing. After processing, there was no significant difference in volume or WBC count between collection kits although some degree of cell loss (1\%-29\%) was documented in $25 \%$ of AUTO- and $51 \%$ of WBC-kit units. Seven patients had greater than $10 \%$ cell loss in multiple successive collections. There was no correlation between cell loss, collection kit, MM subtype, laboratory studies, or mobilization regimen in these patients (data not shown).

An initial analysis of CD34 yield by collection kit suggested improved performance with the WBC-kit (Table 3). The WBC-kit had a higher mean \%CD34 and CD34/kg yield per unit and a 23\% higher CD34/kg yield per mobilization cycle $(\mathrm{p}=0.048)$ than the AUTO-kit.

\section{CD34/kg yield by day and collection kit}

We initially examined the CD34/kg yield per procedure by mobilization regimen, collection kit, and collection day (Fig. 2A). Without exception, patients mobilized with chemo + GF collected $40 \%$ to $60 \%$ more CD34 cells per collection day $(\mathrm{p}=0.016-0.044)$, and per cycle (Table 4 ), over GF-only patients. When subanalyzed by collection kit, mean CD34/kg yields tended to be higher with chemo + GF mobilization and WBC-kit, particularly on Day $3(\mathrm{CD} 34 / \mathrm{kg}=2.35$ vs. $1, \mathrm{p}=0.02)$. Similar findings were observed when mixed collections (Fig. 1) were included in the analysis ( $\mathrm{p}=0.0019$, not shown). The mean CD34/kg yield per cycle was also higher in chemo + GF patients using the WBC-kit (CD34/kg 13.4 vs. $9.6, \mathrm{p}=0.09$ ). In GF-only patients, the total CD34/ $\mathrm{kg}$ yield was slightly better with the AUTO-kit $(p=0.03)$ although there was no significant difference per collection day between kits (Fig. 2A).

\section{Number of procedures for one APBPCT}

The minimum number of procedures required to collect $3 \times 10^{6} \mathrm{CD} 34 / \mathrm{kg}$ or one APBPCT, and the total number of procedures per cycle, were compared by mobilization regimen and kit (Fig. 2, Table 4). As expected, patients mobilized with chemo + GF underwent fewer procedures than GF-only patients, with $46 \%$ to $67 \%$ collecting one APBPCT in one procedure (Fig. $2 \mathrm{~B}, \mathrm{p}=0.0003$; odds ratio [OR], 13.07; 95\% CI, 2.32-96.48). Most GF-only patients required at least 2 days to collect one APBPCT. Altogether, $84 \%$ of chemo + GF and $75 \%$ of GF-only patients collected one APBPCT within 2 days. Although not significant, approximately $10 \%$ to $15 \%$ more chemo + GF patients 


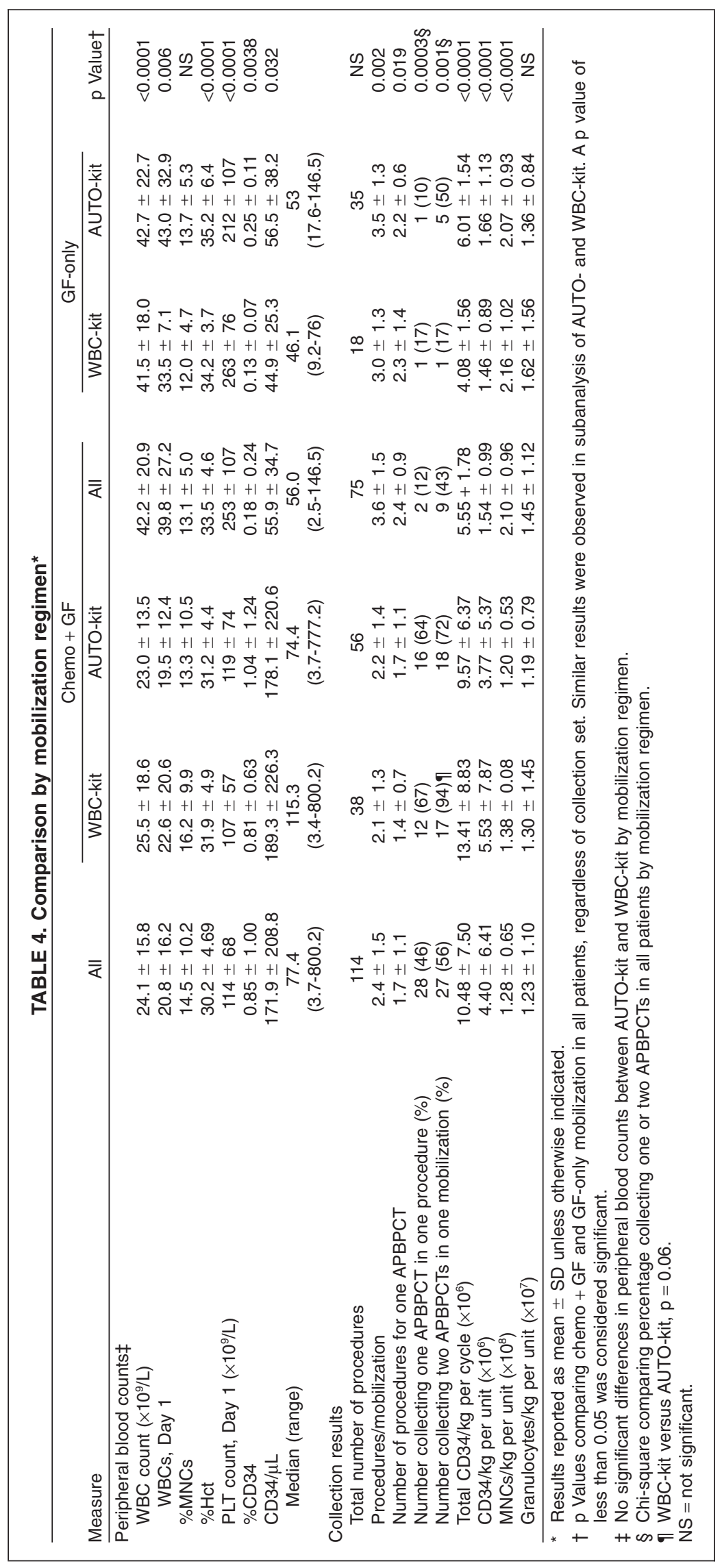


A All Collections
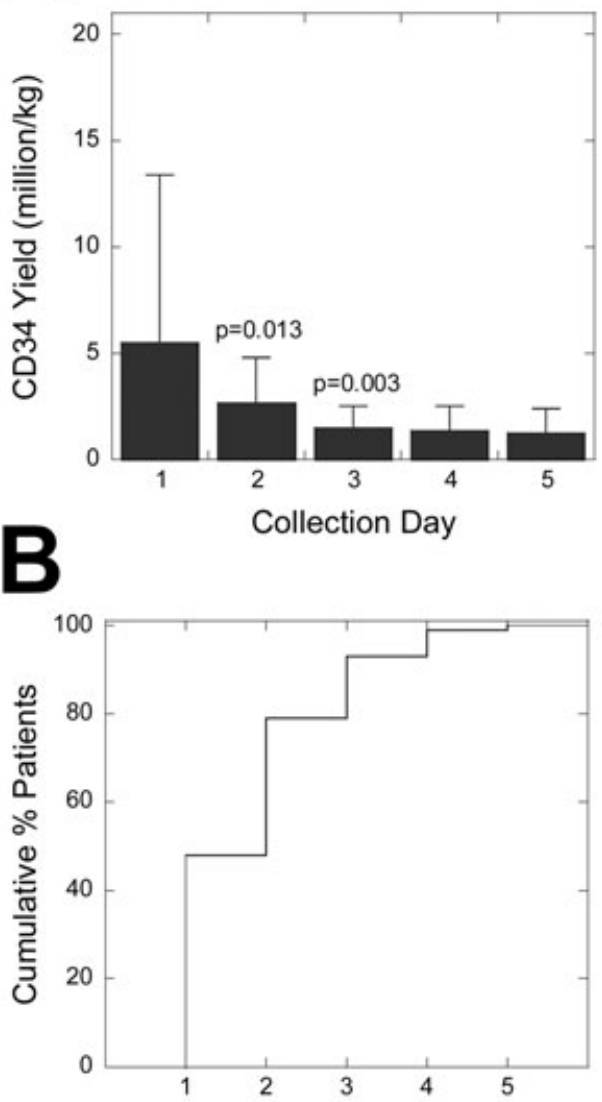

No. Procedures for 1 Transplant

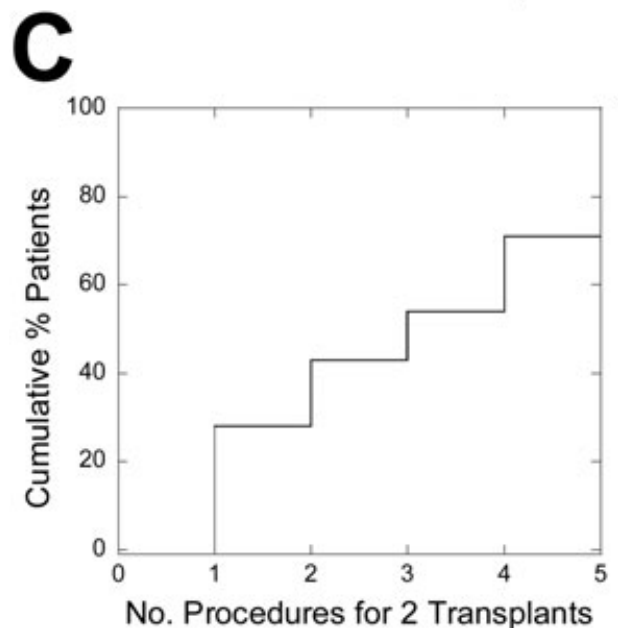

Chemo + GF

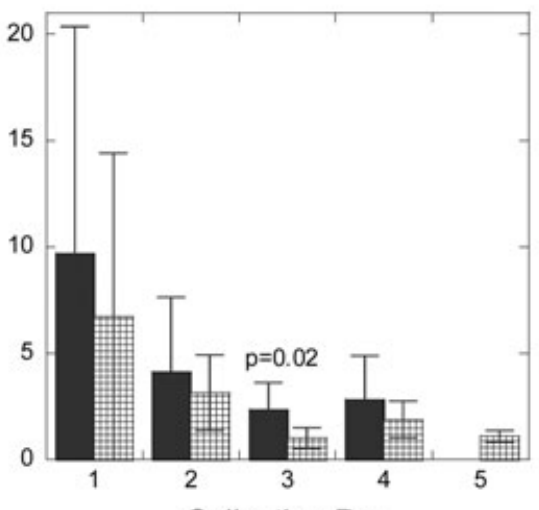

Collection Day

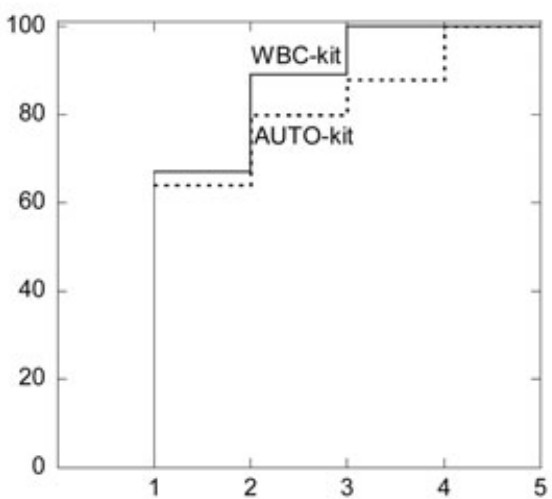

No. Procedures for 1 Transplant

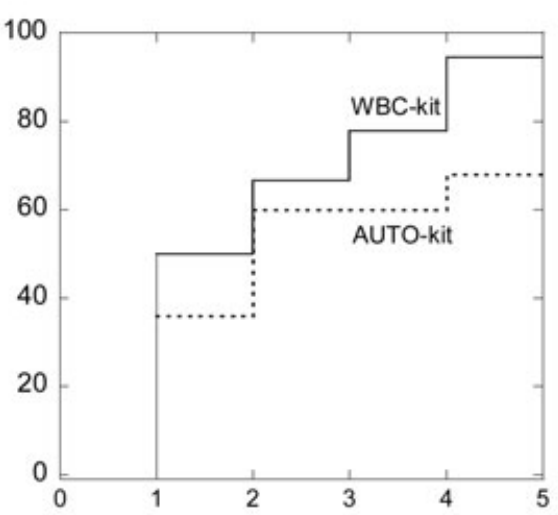

No. Procedures for 2 Transplants
GF-Only
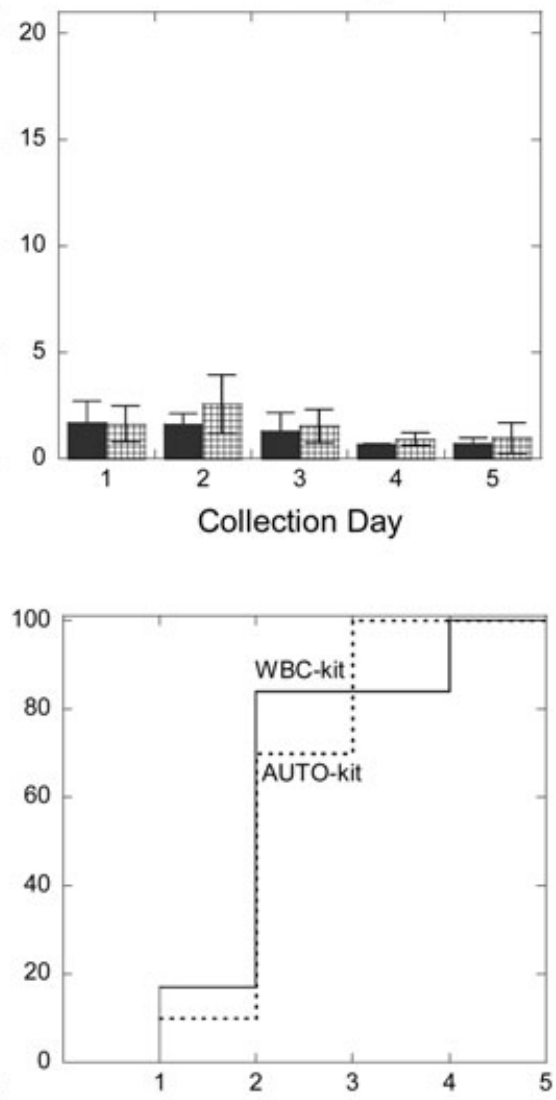

No. Procedures for 1 Transplant

Fig. 2. CD34 yields and collection success rate by mobilization regimen and collection kit. (Row A) CD34/kg yield per day (mean \pm SD) in all collections, regardless of mobilization or kit. Also shown are the CD34/kg yields in chemo + GF-mobilized and GF-only-mobilized patients collected with the WBC-kit ( $\square$ ) and AUTO-kit (羁). (Row B) Cumulative percentage of patients successfully collecting at least $3 \times 10^{6} \mathrm{CD} 34 / \mathrm{kg}$ or one APBPCT per leukapheresis procedure in all patients, chemo + GF-mobilized patients, and GF-only-mobilized patients. Results for WBC-kit (-) and AUTO-kit (- - -) are also shown. (Row C) Cumulative percentage of patients collecting at least $6 \times 10^{6} \mathrm{CD} 34 / \mathrm{kg}$ or two APBPCTs by mobilization regimen and collection kit. 
successfully collected for one APBPCT with the WBC-kit per procedure (Fig. 2B).

\section{Number of procedures for two APBPCTs}

We also examined the success rate to collect $6 \times 10^{6}$ $\mathrm{CD} 34 / \mathrm{kg}$ in a single mobilization cycle (Fig. 2C, Table 3). Overall, $82 \%$ of chemo + GF- versus $37 \%$ of GF-onlymobilized patients collected two APBPCT in a single mobilization cycle $(\mathrm{p}=0.001$; OR, 7.29; 95\% CI, 1.7532.22). In chemo + GF patients, more patients collected for two APBPCTs with the WBC-kit (94\% vs. $72 \%, \mathrm{p}=0.06$ ), with $50 \%$ collecting in one procedure.

\section{CD34 collection rate}

Despite equivalent peripheral CD34 counts and MNC-CE (Table 3), CD34/kg yields tended to be consistently higher with the WBC-kit in chemo + GF-mobilized patients. To explain the latter, we plotted the CD34/kg yield per peripheral CD34 count by kit and mobilization regimen (Figs. 3A and 3B). As reported, there was a linear correlation between CD34 count $(\mathrm{CD} 34 / \mu \mathrm{L})$ and CD34/kg yield when all collections were examined (Fig. 3A) ${ }^{24}$ When examined by kit and mobilization regimen, the fastest CD34 collection rate (slope) was observed using chemo + GF mobilization and WBC-kit. The results were more dramatic when CD34/kg yields were plotted by $\%$ CD34 cells (Fig. 3B, p < 0.05). In chemo + GF patients, a nonlinear relationship was noted with the WBC-kit, resulting in high CD34/ kg yields despite low circulating \%CD34 cells.

\section{Comparison of CD34 collection in individual patients}

A few patients were remobilized and collected using the alternate collection set, including two patients excluded from the final analysis due to poor collection yields (Figs. 3C through 3E). In all patients, the WBC-kit collected more CD34 cells than the AUTO-kit in the first 2 days of collection, regardless of mobilization regimen used ( $p=0.003$, paired t test). The improved collection with the WBC-kit was particularly noteworthy in patients 55 and 128, in which two different mobilization regimens were used.

\section{Effect of peripheral WBC count on CD34 collection}

Five prior studies have reported a decrease in MNC-CE and CD34-CE at elevated peripheral WBC and CD34 counts, particularly at WBC counts greater than $20 \times 10^{9}$ / L. ${ }^{26,30-31,38,51}$ Similarly, we had observed decreased CD34/kg yields and CD34 collection rates in GF-only patients (Fig. 3), who typically had higher peripheral WBC counts
(Table 4). To explore whether WBC count impacted CD34 collection, the mean CD34/kg yield and CD34 collection rate were compared at "high" $\left(>20 \times 10^{9} / \mathrm{L}\right)$ and "low" $\left(<20 \times 10^{9} / \mathrm{L}\right)$ WBC counts as defined by Gidron and colleagues. $^{51}$

In general, the mean CD34/kg yield decreased with increasing peripheral WBC count (Fig. 4A). We also observed a drop in MNC-CE and CD34-CE at high WBC counts with both kits, with a 50\% decrease in CD34-CE with the AUTO-kit (Table 5). The impact of WBC count on CD34 collection was also evident when CD34 collection rate was plotted at high and low WBC counts. Specifically, high WBC counts were associated with a $50 \%$ decrease in CD34 collection rate or slope using the AUTO-kit (Fig. 4B, $\mathrm{p}<0.01$ ). In contrast, high WBC counts had no apparent effect on CD34 collection rates with the WBC-kit (Fig. 4C, $\mathrm{p}=\mathrm{NS})$.

We examined several factors that could potentially impact blood viscosity, laminar flow, and MNC collection in the AUTO-kit design (Table 5). ${ }^{52}$ As expected, high WBC counts were associated with GF-only mobilization. Higher WBC counts were accompanied by higher PLT and RBC counts, particularly in GF-only patients who typically displayed a parallel increase between WBC counts, Hct levels ( $R=0.36, p=0.0014$; Fig. $4 \mathrm{C})$, and PLT counts $(\mathrm{R}=0.49$, $\mathrm{p}=0.03$; not shown). In GF-only patients, there was an inverse relationship between Hct and \%MNC-CE with the AUTO-kit (Fig. 4D). Hct, however, had no independent effect on CD34 collection rates (Fig. 4E). There was no correlation between \%MNC-CE, \%CD34-CE, CD34 yield, and CD34 collection rates with either premobilization or daily PLT counts (not shown), ${ }^{17,22,23}$ serum protein, albumin, ${ }^{31}$ or immunoglobulin levels. A recent fibrinogen, C-reactive protein, or whole blood viscosity was not available for analysis in most patients. ${ }^{52}$

\section{CD34 collection in lymphoma patients by collection set}

To test whether our observations were unique to $\mathrm{MM}$ patients, we performed a retrospective analysis of PBPC collection in adult autologous lymphoma patients. Unlike MM patients, lymphoma patients were a very heterogenous population with a wide range in patient age, prior treatment (not shown), chemotherapy-associated mobilization, and mobilization failures ${ }^{53,54}$ (Table 6). In general, slightly more lymphoma patients collected in one procedure with the WBC-kit (Fig. 5A). When normalized for peripheral CD34 counts, the WBC-kit performed slightly better than the AUTO-kit (Fig. 5B). In Hodgkin's lymphoma, a nonlinear relationship was again observed between CD34 yields and \%CD34 cells (Fig. 5C, p < 0.01). In contrast to $\mathrm{MM}$, the peripheral WBC count had no impact on CD34 collection rates in lymphoma patients (Fig. 5D, $\mathrm{p}=\mathrm{NS}$ ). 
A All Collections

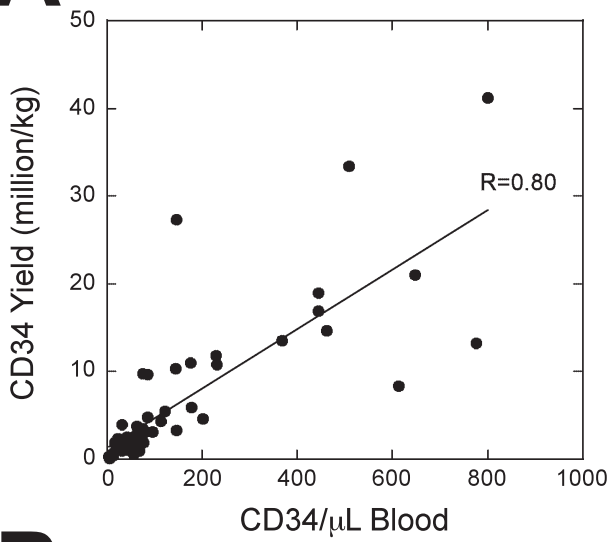

B

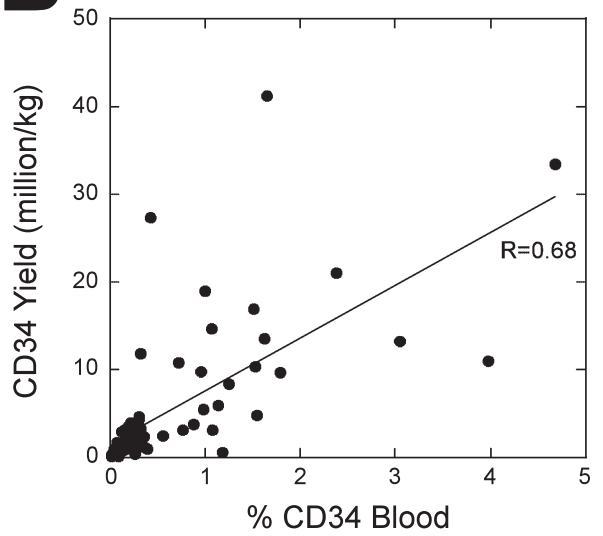

C

Patient 55

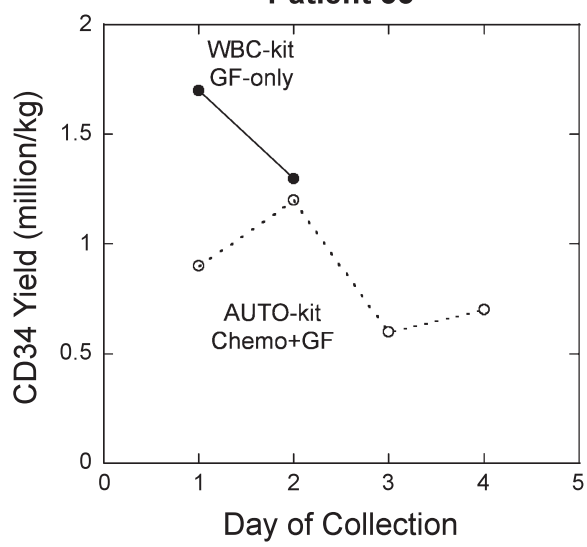

Chemo + GF
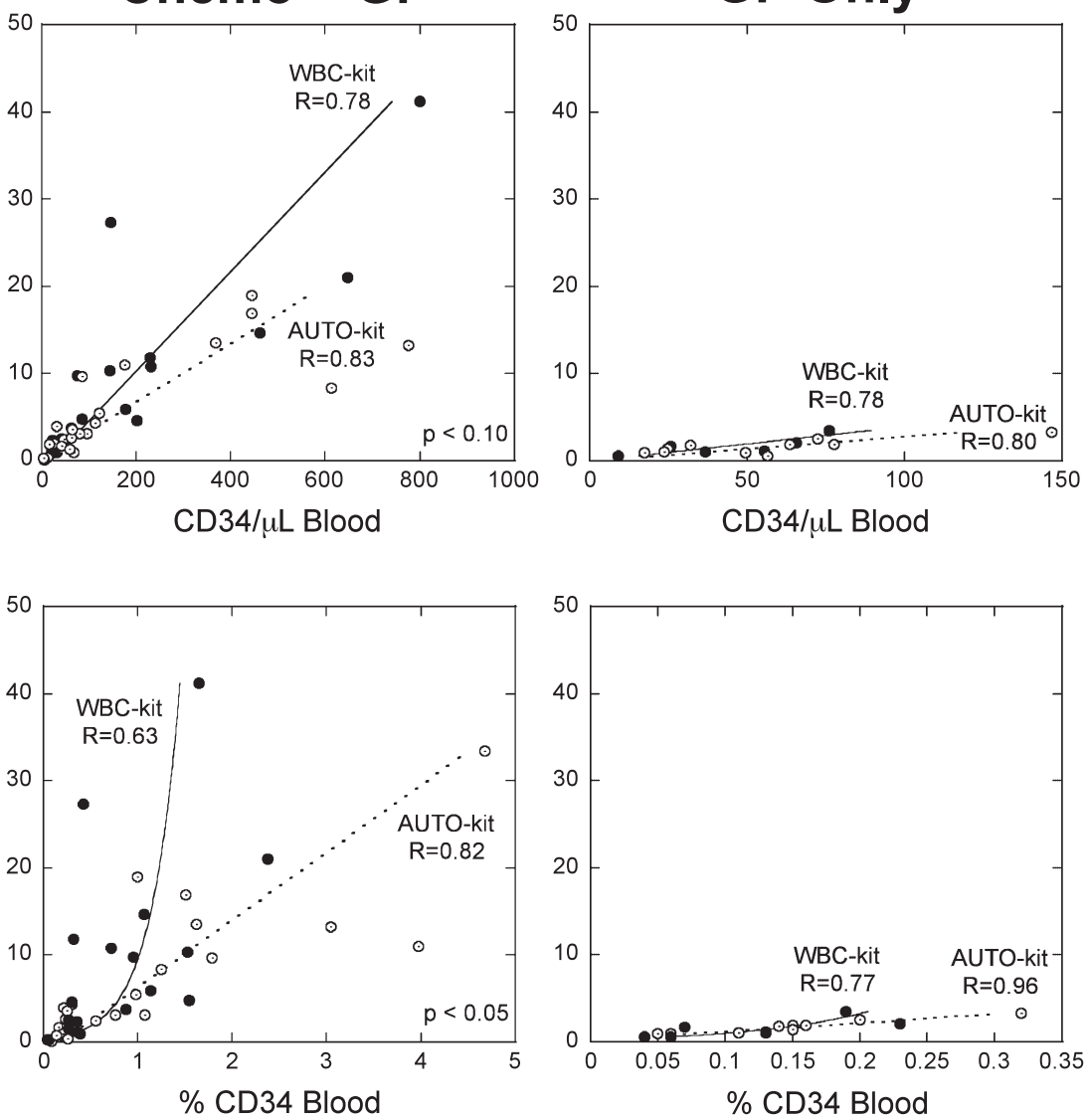

GF-Only

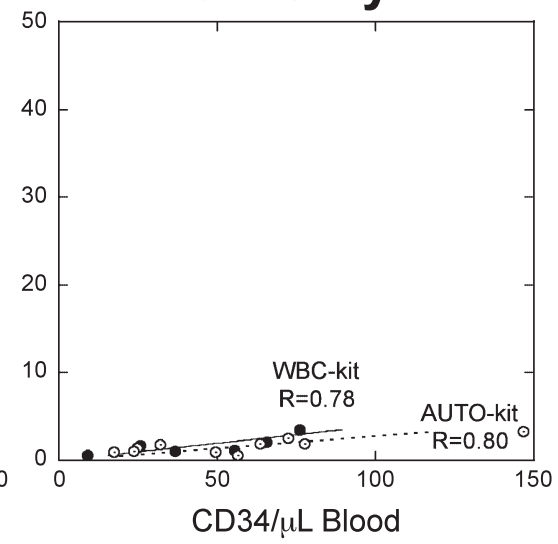

CD34/uL Blood
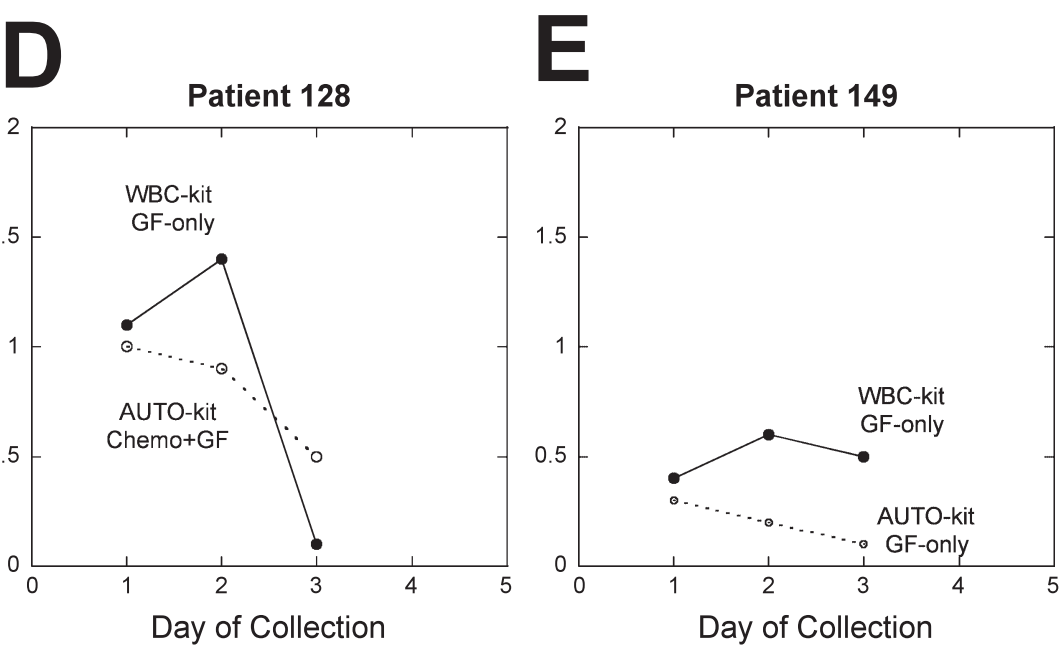

Fig. 3. CD34 collection rate relative to peripheral CD34 counts. (Row A) CD34/kg yield per peripheral CD34/ $\mu \mathrm{L}$ in all patients, chemo + GF patients, and GF-only-mobilized patients. The collection rate and correlation coefficients for all collections, WBC-kit (一), and AUTO-kit only (- -) were determined by linear regression (correlation probabilities $p=0.05$ to $p<0.0001$ ). A difference in collection rate (slope) was observed at $90 \%$ CI between AUTO-kit (90\% CI, 12.48-21.06) and WBC-kit $\left(90 \%\right.$ CI, 22.58-39.04). ${ }^{50}$ (Row B) $\mathrm{CD34} / \mathrm{kg}$ yield per procedure by peripheral \%CD34 cells in all patients, chemo + GF patients (correlation $\mathrm{p}=0.02-0.0001$ ), and GF-only-mobilized patients ( $p=0.15-0.54)$ by collection kit. The collection rate or slope between AUTO-kit (95\% CI, 0.09-0.17) and WBC-kit (95\% CI, 0.68-0.73) was significant. (C-E) Direct comparison of CD34/kg yield per procedure in three remobilized patients by collection kit and mobilization regimen, including two poor mobilizers that were excluded from postcollection analysis. 

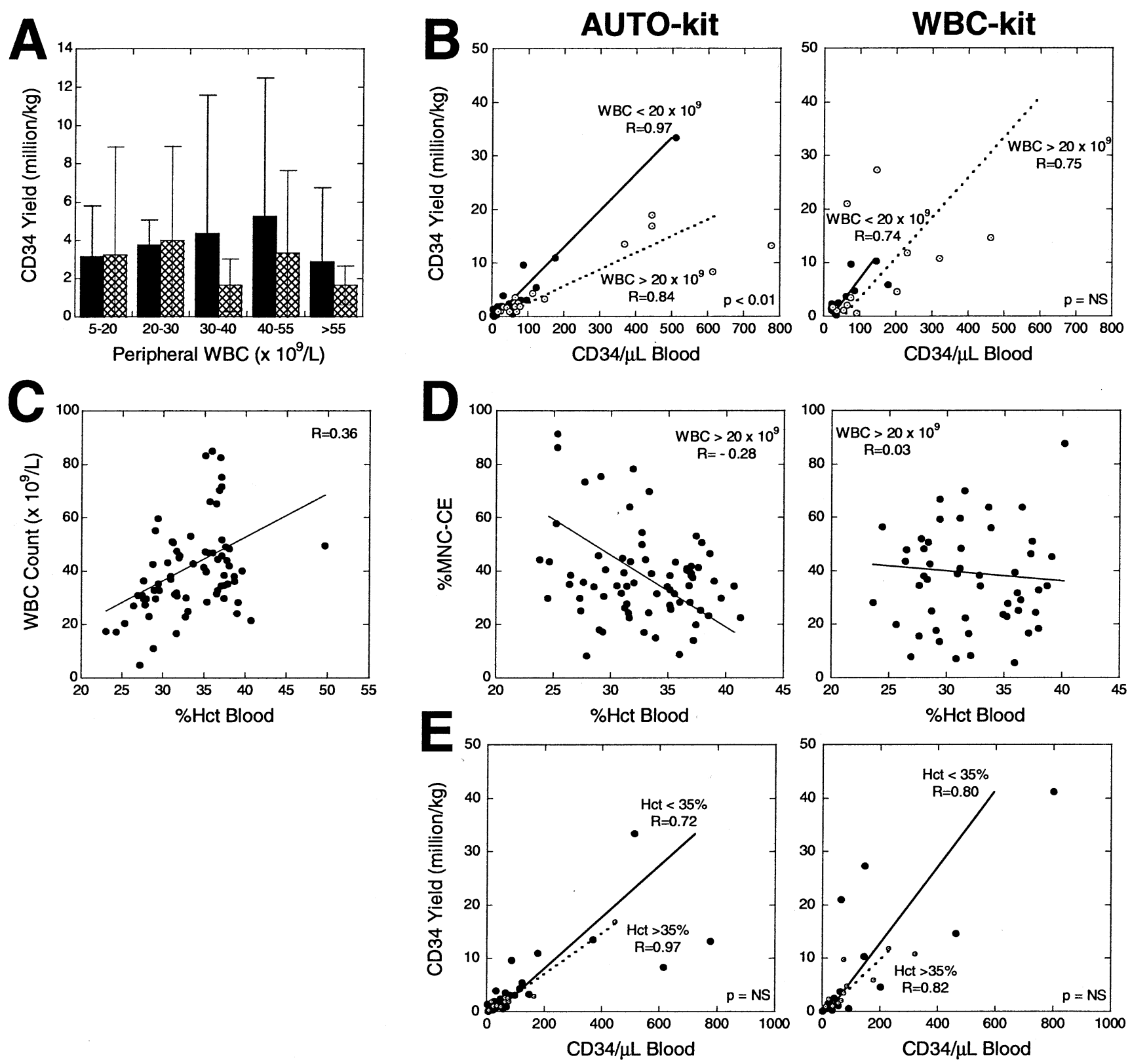

Fig. 4. Effect of peripheral WBC count and Hct on CD34 collection. (A) CD34/kg yield (mean \pm SD) relative to peripheral WBC count using the WBC-kit ( $\square$ ) or AUTO-kit ( (B) CD34 collection rate in the AUTO-kit and WBC-kit at low WBC $\left(<20 \times 10^{9} / \mathrm{L},-\right)$ and high peripheral WBC counts $\left(>20 \times 10^{9} / \mathrm{L},---\right.$; correlation probabilities $\left.\mathbf{p}<0.001-\mathbf{0 . 0 0 0 1}\right)$. $\mathrm{p}$ Values refer to the collection rate or slope at high and low WBC counts, as calculated from $95 \%$ and $99 \% \mathrm{CI}^{50}$ (C) Correlation between peripheral Hct (\%) and the WBC count in GF-only-mobilized patients (correlation $p=0.002$ to $p<0.0001$ ). (D) Correlation between Hct (\%) and \%MNC-CE in GF-onlymobilized patients using the AUTO-kit or WBC-kit. (E) CD34 collection rate by \%Hct using the AUTO-kit and WBC-kit in GF-onlymobilized patients.

\section{Effect of collection kit on PLT counts}

One stated disadvantage of the WBC-kit for PBPC collection is the risk of procedure-related thrombocytopenia, with some studies reporting a $30 \%$ to $43 \%$ decrease in PLT count per procedure. ${ }^{40-42,55,56}$ To examine the latter, we calculated the absolute and percentage change in daily PLT count. The mean decrease in daily PLT count was $12 \%$ (range, $0 \%$ to $53 \%$ ) with no significant difference between kits (Table 3). The AUTO-kit, however, had the greatest intrapatient change in PLT count ( $p=0.0005$ vs. WBC-kit, $\mathrm{p}=0.05$; paired $\mathrm{t}$ test).

We also reviewed the transfusion record of each patient for any PLT or RBC transfusions during the course 


\begin{tabular}{|c|c|c|c|}
\hline \multirow[b]{2}{*}{ Measure } & \multicolumn{2}{|c|}{ Peripheral WBC count $\left(\times 10^{9} / \mathrm{L}\right)$} & \multirow[b]{2}{*}{ p Value ${ }^{*}$} \\
\hline & Low & High & \\
\hline \multicolumn{4}{|l|}{ Peripheral blood counts $\dagger$} \\
\hline WBC count $\left(\times 10^{9} / \mathrm{L}\right)$ & $11.8 \pm 4.6$ & $39.4 \pm 15.0$ & $<0.0001$ \\
\hline$\%$ MNCs & $15.1 \pm 8.3$ & $9.4 \pm 4.5$ & $<0.0001$ \\
\hline MNCs $\left(\times 10^{9} / \mathrm{L}\right)$ & $1.76 \pm 0.9$ & $3.7 \pm 1.6$ & $<0.0001$ \\
\hline$\% \mathrm{Hct}$ & $29.5 \pm 4.9$ & $32.6 \pm 4.1$ & 0.00013 \\
\hline PLT count $\left(\times 10^{9} / \mathrm{L}\right)$ & $86.2 \pm 38.9$ & $157.0 \pm 76.0$ & $<0.0001$ \\
\hline $\mathrm{CD} 34 / \mu \mathrm{L}$ & $73.7 \pm 98.7$ & $190.0 \pm 221.9$ & 0.01 \\
\hline Median (range) & $44.7(2.5-510.1)$ & $74.3(16.3-800.2)$ & \\
\hline \multicolumn{4}{|l|}{ Serum proteint } \\
\hline Total protein (g/dL) & $6.5 \pm 1.3$ & $6.2 \pm 0.9$ & NS \\
\hline Albumin ( $/ \mathrm{dL})$ & $3.4 \pm 0.4$ & $3.7 \pm 0.6$ & 0.06 \\
\hline \multicolumn{4}{|c|}{ Immunoglobulin (mg/dL) } \\
\hline IgG, median & 614 & 572 & NS \\
\hline IgA, median & 47 & 32 & NS \\
\hline IgM, median & 23 & 27 & NS \\
\hline \multicolumn{4}{|l|}{ Mobilization } \\
\hline Chemo + GF & 25 & 18 & 0.0019 \\
\hline GF-only & 2 & 14 & 0.0019 \\
\hline \multicolumn{4}{|l|}{ Collection yield $\dagger$} \\
\hline $\mathrm{MNCs} / \mathrm{kg}\left(\times 10^{8}\right)$ & $1.03 \pm 0.47$ & $1.69 \pm 0.82$ & $<0.0001$ \\
\hline WBC-kit & $1.08 \pm 0.45$ & $1.78 \pm 0.79$ & 0.002 \\
\hline AUTO-kit & $1.10 \pm 0.48$ & $1.83 \pm 1.13$ & $<0.0001$ \\
\hline $\mathrm{CD} 34 / \mathrm{kg}\left(\times 10^{6}\right)$ & $3.40 \pm 4.77$ & $4.05 \pm 6.23$ & NS \\
\hline Median & 2.1 & 1.9 & \\
\hline WBC-kit & $3.44 \pm 2.62$ & $5.43 \pm 8.89$ & NS \\
\hline AUTO-kit & $3.37 \pm 5.76$ & $3.19 \pm 3.90$ & NS \\
\hline \multicolumn{4}{|l|}{ CE† } \\
\hline$\% M N C-C E$ & $43.3 \pm 21.4$ & $35.1 \pm 17.3$ & 0.07 \\
\hline WBC-kit & $40.0 \pm 19.7$ & $35.9 \pm 22.8$ & NS \\
\hline AUTO-kit & $45.4 \pm 37.0$ & $34.5 \pm 12.9$ & 0.10 \\
\hline$\%$ CD34-CE & $44.6 \pm 4.4$ & $23.8 \pm 13.6$ & 0.017 \\
\hline WBC-kit & $37.5 \pm 20.0$ & $25.9 \pm 18.2$ & NS \\
\hline AUTO-kit & $49.2 \pm 5.5$ & $22.3 \pm 9.3$ & 0.05 \\
\hline \multicolumn{4}{|c|}{$\begin{array}{l}\text { * Comparison of peripheral WBC in patients collected with either the WBC-kit or AUTO- } \\
\text { kit only. Results reported as mean } \pm \text { SD unless otherwise indicated. A p value of less } \\
\text { than } 0.05 \text { was considered significant. NS }=\text { not significant and } p>0.10 \text {. } \\
\dagger \text { No significant difference between AUTO- and WBC-kit by peripheral WBC count. }\end{array}$} \\
\hline
\end{tabular}

of PBPC collection (Table 3). Only one patient required a PLT transfusion. This patient received a PLT transfusion the day before starting PBPC collection for a PLT count of $12 \times 10^{9} / \mathrm{L}$. This patient underwent four procedures using the WBC-kit without additional transfusion support. No patient studied required a RBC transfusion during the course of PBPC collection.

\section{Infusion reaction rate by kit and mobilization}

Most patients underwent at least one APBPCT and 30\% received two APBPCTs, for a total of 88 infusions (Table 7). The mean reaction rate for all infusions was $26 \%$, with a higher reaction rate with AUTO-kit units (33\%). Most reactions were mild and included nausea and vomiting (83\%), cough (17\%), cramps (9\%), fever, and rigors (4\%). Five reactions were relatively severe with cardiopulmonary symptoms. Reactions were significantly associated with GF-only mobilization ( $\mathrm{p}<0.0001$; relative risk, 4.1; OR, 8.1; 95\% CI, 2.4-27.9). Although GF-only patients accounted for only $25 \%$ of all APBPCTs, they comprised nearly $60 \%(13 / 23)$ of all infusion reactions.

Prior studies have reported a link between PBPC infusion reactions, DMSO dose, and the number of contaminating granulocytes. ${ }^{57-60}$ In general, the total granulocyte yield $\left(3.61 \times 10^{9}\right.$; $\mathrm{p}=0.0001)$, granulocytes $/ \mathrm{kg}\left(4.07 \times 10^{7}\right.$; $\mathrm{p}=0.0001)$, and volume infused (417 mL) were higher in units associated with infusion reactions (Fig. 6). When reactions were examined by mobilization regimen, the granulocyte dose and volume were significantly higher in GF-only units ( $p<0.00001)$, particularly when collected with the AUTO-kit $\left(5.19 \times 10^{7}\right.$ granulocytes $\left./ \mathrm{kg}, \mathrm{p}=0.0006\right)$. Among severe reactions, granulocyte doses averaged $6.31 \times 10^{7} / \mathrm{kg}$ for GF-only units collected with the AUTO-kit.

\section{Engraftment}

All patients received an equivalent CD34/kg dose per transplant, regardless of collection kit or mobilization regimen. There was no significant difference in time to WBC or PLT engraftment. Engraftment times were consistent with previously published studies from our institution. ${ }^{47}$

\section{DISCUSSION}

Several semi- and fully automated apheresis platforms are available for the collection of peripheral CD34 cells. ${ }^{32-44}$ Since its introduction in 1998, the AUTO-kit has been broadly implemented at many institutions. Among the cited advantages of the AUTO-kit are an automated interface and anticoagulant management, increased interface stability, decreased operator oversight, decreased citrate reaction rates, a smaller product volume, and increased product purity with reductions in PLT and granulocyte contamination. ${ }^{40-42}$ Observed disadvantages of the AUTOkit are an increase in collection time, technical difficulties leading to skipped MNC harvests, and inferior collection yields at low peripheral CD34 counts. ${ }^{39,40,42}$

Although we had routinely used the AUTO-kit in adult patients since January 1998, we used the WBC-kit for PBPC collection in children, in remobilized patients, and in adults with falling collection yields. Because the WBCkit was anecdotally associated with improved collection yields in many patients, we designed a prospective randomized trial using the WBC-kit or AUTO-kit in MM 
A

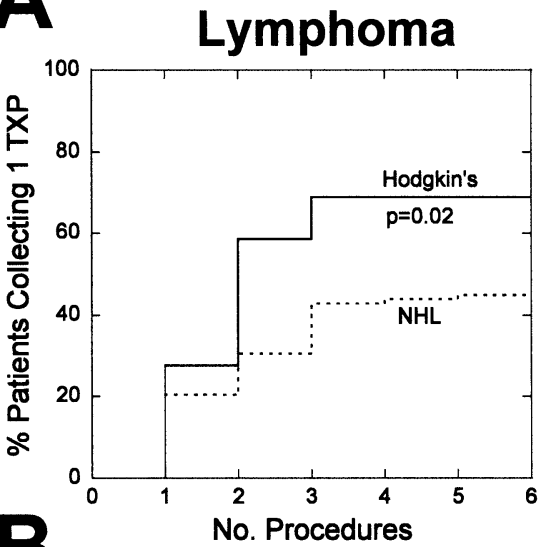

Hodgkin's
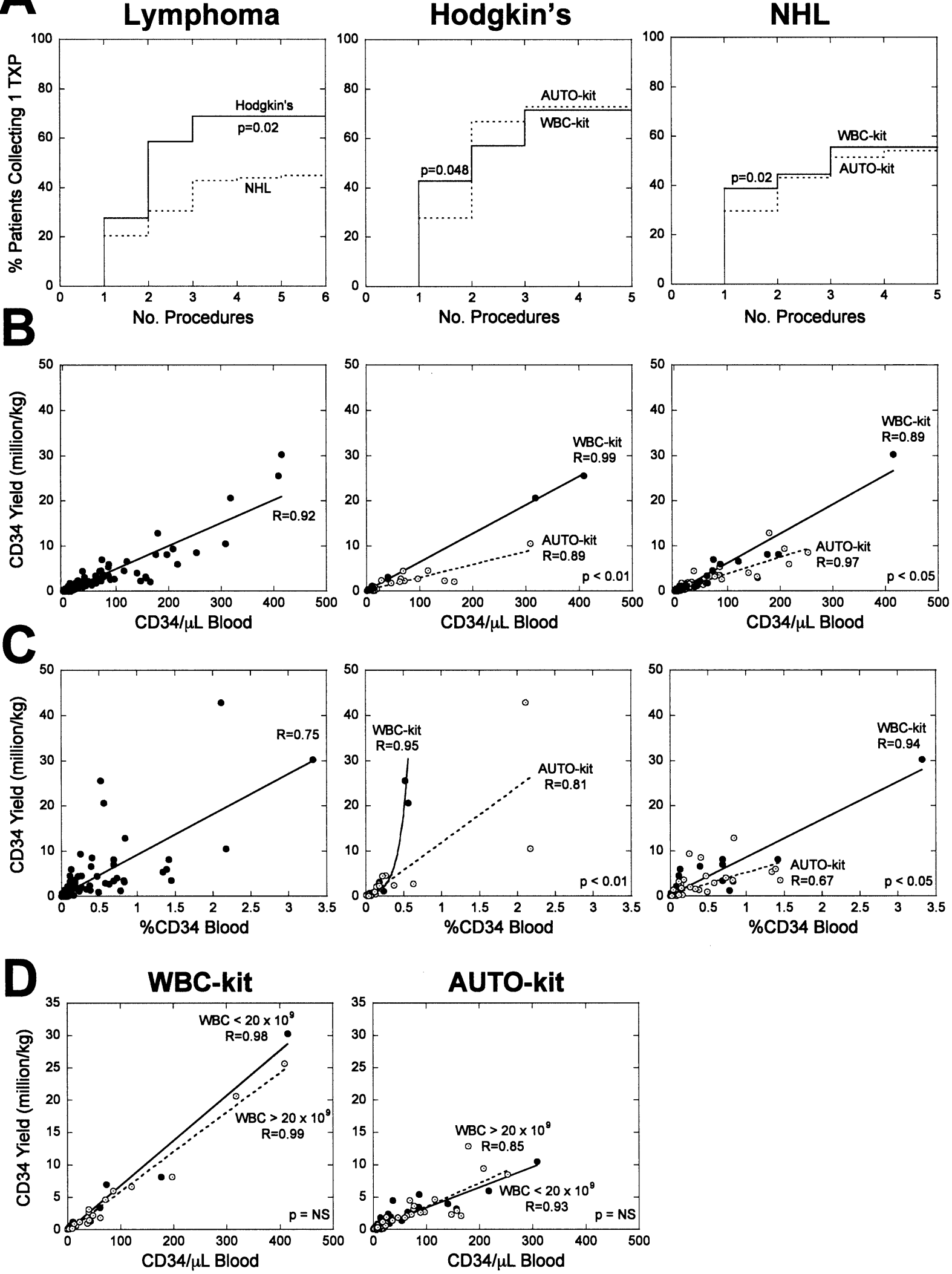


\begin{tabular}{|c|c|c|c|c|}
\hline \multirow[b]{2}{*}{ Measure } & \multirow[b]{2}{*}{ All patients } & \multicolumn{3}{|c|}{ Collection set } \\
\hline & & WBC-kit & AUTO-kit & $\mathrm{p}$ Value ${ }^{*}$ \\
\hline \multicolumn{5}{|l|}{$\overline{\text { Transplant }}$} \\
\hline Number of transplants & 88 & 35 & 45 & - \\
\hline Number of patients receiving transplants & 63 & 24 & 33 & - \\
\hline Number of patients with two APBPCTs & 25 & 11 & 12 & - \\
\hline CD34/kg per APBPCT† & $4.22 \pm 1.81$ & $4.52 \pm 2.64$ & $4.0 \pm 1.53$ & NS \\
\hline \multicolumn{5}{|l|}{ Infusion reaction $(\%) \ddagger$} \\
\hline No reaction & $65(73)$ & $28(80)$ & $30(67)$ & NS \\
\hline Infusion reaction & $23(26)$ & $7(20)$ & $15(33)$ & $0.18 \ddagger$ \\
\hline Mild & $18(20)$ & $6(17)$ & $11(24)$ & NS \\
\hline Severe & $5(6)$ & $1(3)$ & $4(9)$ & $0.18 \ddagger$ \\
\hline \multicolumn{5}{|l|}{ Engraftment (days) $\dagger$} \\
\hline ANC $>500 \times 10^{9} / \mathrm{L} \S$ & $11.5 \pm 0.8$ & $11.7 \pm 1.0$ & $11.6 \pm 0.7$ & NS \\
\hline PLT $>20 \times 10^{9} / \mathrm{L} \emptyset$ & $12.5 \pm 3.3$ & $13.1 \pm 4.9$ & $12.6 \pm 2.3$ & NS \\
\hline PLT $>50 \times 10^{9} / \mathrm{L}$ & $17.9 \pm 6.5$ & $18.0 \pm 8.0$ & $18.1 \pm 6.0$ & NS \\
\hline \multicolumn{5}{|c|}{$\begin{array}{l}\text { * Comparison by PBPC collection kit using two-tailed t-test unless indicated otherwise. A p value of less than } 0.05 \text { was considered signifi- } \\
\text { cant. } \\
\dagger \text { Results reported as mean } \pm \text { SD. } \\
\text { ‡ Chi-square. } \\
\S \text { Sustained absolute neutrophil count (ANC) of more than } 0.5 \times 10^{9} / \mathrm{L} .{ }^{47} \\
\text { ๆ Sustained PLT count of more than } 20 \times 10^{9} / \mathrm{L} \text { or more than } 50 \times 10^{9} / \mathrm{L} \text { in the absence of PLT transfusion for } 72 \text { hours. }^{47} \\
\text { NS }=\text { not significant. }\end{array}$} \\
\hline
\end{tabular}

Chemo + GF patients were also more likely to collect sufficient CD34+ cells for two transplants (Fig. 2, Table 4). Although some authors have claimed equivalent CD34 collections with GF-only, ${ }^{61-63}$ our results agree with more recent studies showing improved mobilization with chemo + GF in MM. ${ }^{18,19}$ Contrary to recent reports, ${ }^{17,22,23}$ neither premobilization nor Day 1 PLT counts were helpful in predicting successful CD34 collection, probably because the highest PLT counts were associated with GF-only mobilization ( $\mathrm{p}=0.0005$, Table 3 ).

We also observed a higher daily success rates with the WBC-kit in chemo + GF-mobilized patients. Overall, 10\% to $15 \%$ more patients successfully collected per procedure with the WBC-kit, with more than $90 \%$ collecting for two APBPCTs (Fig. 2, Table 3). Even among poor mobilizers, the WBC-kit resulted in higher daily CD34/kg yields despite dismal peripheral CD34 counts and CD34/kg yields (Fig. 2D,E). These results agree with Morton and colleagues $^{37}$ who observed a higher success rate per collection with the WBC-kit over the Haemonetics MCS-3P, especially for target yields of greater than $5 \times 10^{6} \mathrm{CD} 34 / \mathrm{kg}$. They also agree with Wilke and coworkers ${ }^{39}$ who reported comparatively better CD34 yields with the WBC-kit at low CD34 concentrations $(<10 \mathrm{CD} 34 / \mu \mathrm{L}, \mathrm{p}=0.012)$. Although some centers have been reluctant to use the WBC-kit due to concerns of procedure-related thrombocytopenia, ${ }^{35,41,55,56}$ we did not encounter clinically significant thrombocytopenia in our patients in agreement with other investigators (Table 2). ${ }^{34,43}$

The WBC-kit also displayed a higher CD34 collection rate in certain populations, depending on underlying disease and mobilization regimen. Specifically, the
CD34/kg collection rate per peripheral CD34/ $\mu \mathrm{L}$ count was twofold higher with the WBC-kit in chemo + GF MM and Hodgkin's lymphoma patients (Fig. 3 and 5). When examined by peripheral \%CD34, the CD34 collection was nonlinear, resulting in high CD34/ kg yields even at relatively low $\mathrm{CD} 34$ concentrations. These results were not observed in NHL and GF-only-mobilized MM patients.

Finally, the WBC-kit appeared less sensitive than the AUTO-kit to high peripheral WBC counts. Although both kits exhibited a decrease in MNC-CE and CD34-CE with increasing peripheral WBC counts (Table 4), the impact was worse with the AUTO-kit. The AUTO-kit had a $50 \%$ decrease in CD34-CE at WBC counts greater than $20 \times 10^{9} / \mathrm{L}$, accompanied by a twofold decrease in CD34 collection rate (Fig. 3, p < 0.01). The decrease in CD34 collection rate was not observed with the WBC-kit, or in lymphoma patients, suggesting that the phenomenon is unique for the AUTO-kit in MM.

A potential adverse effect by elevated peripheral WBC and MNC counts on CE has been reported by others. $^{26,30,31,38,51}$ In an early study, Benjamin and colleagues ${ }^{27}$ noted an inverse relationship between the peripheral MNC count and MNC-CE, with the best CE observed at low WBC and MNC counts. Similar findings were reported by Heuft and colleagues ${ }^{38}$ and Gidron and colleagues, ${ }^{51}$ who noted a decrease in the calculated CD34-CE at higher WBC and CD34 counts. Gidron, in particular, reported a significant decrease in CD34-CE at peripheral WBCs greater than $20 \times 10^{9} / \mathrm{L} \quad(\mathrm{p}<0.0001)$, prompting the authors to caution against GF-only mobilization regimens. ${ }^{51}$ Finally, Burgstaler and colleagues ${ }^{30}$ reported a significant decrease in CD34 yields (55\%-77\%), accompanied 

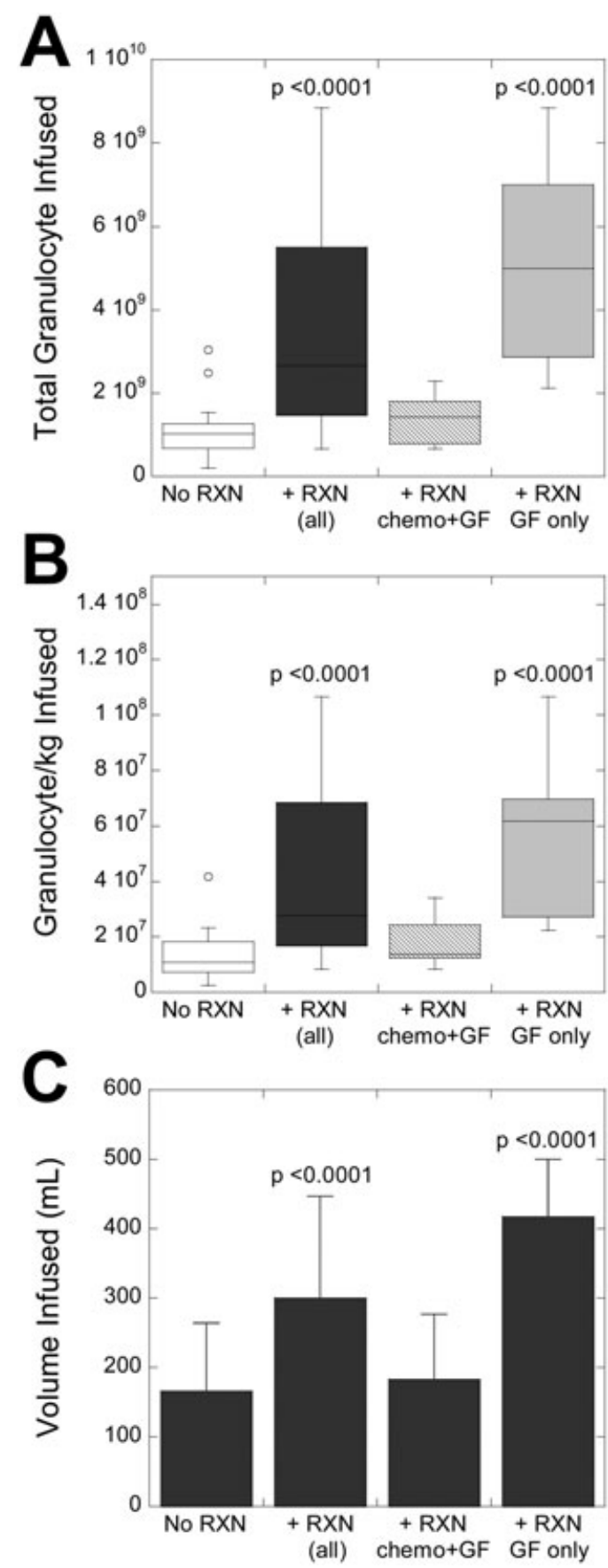

Fig. 6. The influence of PBPC mobilization on infusion reactions (RXN). (A) Total granulocyte dose per transplant in patients with no reaction $(\square)$, granulocyte dose in all infusion reactions $(\square)$, infusion reactions in chemo + GF-mobilized (\$), and GF-only-mobilized patients ( $\square$ ). Data displayed as a box plot, showing median, 25th and 75th quartile and data range (whiskers). (B) Granulocyte dose/kg body weight. (C) Mean volume infused $(\mathrm{mL}$, mean $\pm \mathrm{SD}$ ) per APBPCT in patients with and without an infusion reaction. $p$ Values determined by two-tailed $t$ test. by a twofold increase in WBC contamination, in units collected at WBC counts of greater than $35 \times 10^{9} / \mathrm{L}$ and flow rates greater than $60 \mathrm{~mL} / \mathrm{min}$.

Benjamin and coworkers ${ }^{26}$ hypothesized that all continuous flow centrifugation devices may be susceptible to a fall-off in CE with rising WBC and CD34 counts due to the fixed size of the collection aperture. These authors speculated that at low WBC counts, the MNC band is narrow relative to the collection channel, permitting an efficient collection of the entire MNC layer. CE decreases with increasing MNC and WBC counts as the MNC layer exceeds the fixed diameter of the collection channel and an increasing percentage of MNC escape collection. Our results suggest that the dual-stage design of the AUTO-kit may exacerbate the effect of elevated WBC on CD34 collection rate and efficiency in MM patients.

Several factors could synergistically depress CE with the AUTO-kit design in GF-only mobilized MM patients via effects on blood viscosity, laminar flow, and cell separation. Blood viscosity is sensitive to increases in Hct, WBCs, PLTs, fibrinogen, immunoglobulin, and other plasma proteins. ${ }^{52}$ Hct and leukocrit, in particular, are major and synergistic contributors to whole blood viscosity, that are both increased with GF-only mobilization. The additional impact of paraprotein is variable; however, blood viscosity is elevated in more than $50 \%$ of $\mathrm{MM}$ patients when corrected for Hct. $^{52}$ G-CSF may further increase plasma and whole blood viscosity due to increases in fibrinogen, Factor VIII and von Willebrand factor, PLT count, and PLT activation. ${ }^{64-66}$ In the Fenwal Amicus, high PLT counts and increased plasma viscosity are both theorized to interfere with cell collection, leading to decreased MNC-CE, lower CD34/kg yields, and missed collection cycles. ${ }^{67}$ Although we were unable to demonstrate a direct association between CD34 collection and paraprotein levels, it is noteworthy that only MM patients demonstrated a drop in the CD34 collection rate at high WBC counts.

Finally, we compared infusion and engraftment data by kit and mobilization. All patients were transplanted with equivalent CD34/ kg doses and had similar engraftment times. There was, however, a higher incidence of infusion reactions, accompanied by a higher granulocyte dose per APBPCT, with GF-only units. Zambelli and colleagues were the first to report an association between fever and granulocyte dose $\left(>10^{9} / \mathrm{kg}\right),{ }^{57,58}$ followed by Calmels and coworkers, ${ }^{59}$ who reported a higher median granulocyte content $\left(3.3 \times 10^{9}\right)$ in units associated with adverse reactions. Likewise, we observed a significantly higher total granulocyte content and granulocyte/kg dose with infusion reactions, particularly with GF-only units (Fig. 6).

Our study differs significantly from prior studies examining the AUTO-kit, ${ }^{39-44}$ and other collection platforms, both in design and in postcollection analysis. 
Although primary disease and mobilization regimen are known to be significant factors influencing CD34 mobilization, ${ }^{16-20}$ most studies have examined device performance in a heterogenous pool of patients and normal donors, often using historical data for comparison purposes. ${ }^{34-39,41-43} \mathrm{~A}$ few studies have performed 2-day randomized crossover studies to control for patient-related factors. ${ }^{34-37,43}$ Although there are many advantages to a crossover design, our study allowed us to compare the collection kit performance over several consecutive days in individual patients. As a consequence, we were able to extend our analysis to the number of procedures/ mobilization, the success rate per APBPCT, and infusion reaction rate. Our results highlight the need to consider the impact of patient diagnosis, mobilization regimen, and CD34 collection rates in the evaluation of new apheresis devices.

In summary, we have performed the first randomized, prospective study specifically comparing the AUTO- and WBC-kits for PBPC collection in MM. We demonstrate that the WBC-kit, combined with chemo + GF mobilization, improves CD34 yields in MM patients. GF-only mobilization was associated with more procedures and decreased CE, particularly with the AUTO-kit due to a fall-off in CD34 collection rates at higher WBC counts. We also showed an increase in infusion reaction rates and higher granulocyte doses with GF-only and AUTO-kit units. Because MM patients represent a significant proportion of our transplant population, we have discontinued the use of the AUTO-kit for all collections. In addition, there has been a significant shift toward chemo + GF mobilization for all patients unless medically contraindicated.

\section{ACKNOWLEDGMENTS}

The authors thank Mike Meade, BSN, MBA, and the entire nursing staff of the Apheresis Procedure Unit for their participation and care of patients during the period of the study; Terry Tallmadge, MT, Cell Therapy Laboratory, for help in data collection; and Shin Mineishi, MD, Internal Medicine and Director, Bone Marrow Transplant Program, for useful discussions.

\section{CONFLICT OF INTEREST}

The authors declare that they have no conflicts of interest relevant to the submitted manuscript.

\section{REFERENCES}

1. Copelan EA. Hematopoietic stem-cell transplantation. $\mathrm{N}$ Engl J Med 2006;354:1813-26.

2. Attal M, Moreau P, Avet-Loiseau H, Harousseau JL. Stem cell transplantation in multiple myeloma. Hematology 2007;311-6.
3. Koreth J, Cutler CS, Djulbegovic B, Behl R, Schlossman RL, Munshi NC, Richardson PG, Anderson KC, Soiffer RJ, Alyea EP. High-dose therapy with single autologous transplantation versus chemotherapy for newly diagnosed multiple myeloma: a systematic review and meta-analysis of randomized controlled trials. Biol Blood Marrow Transplant 2007;13:183-96.

4. Mehta J, Tricot G, Jagannath S, Ayers D, Singhal S, Siegel D, Desikan K, Nunshi N, Fassas A, Mattox S, Vesole D,

Crowley J, Barlogie B. Salvage autologous or allogeneic transplantation for multiple myeloma refractory to or relapsing after a first-line autograft. Bone Marrow Transplant 1998;21:887-92.

5. Qazilbash MH, Saliba R, De Lima M, Hosing C, Couriel D, Aleman A, Roden L, Champlin R, Giralt SA. Second autologous or allogeneic transplantation after the failure of first autograft in patients with multiple myeloma. Cancer 2006; 106:1084-9.

6. Attal M, Harousseau JL, Facon T, Guilhot F, Doyen C, Fuzibet JG, Monconduit M, Hulin C, Caillot D, Bouabdallah R, Voillat L, Sotto JJ, Grosbois B, Bataille R. Single versus double autologous stem-cell transplantation for multiple myeloma. N Engl J Med 2003;349:2495-502.

7. Cavo M, Tosi P, Zamagni E, Cellini C, Tacchetti P, Patriarca F, Di Raimondo F, Volpe E, Ronconi S, Cangini D, Narni F, Carubelli A, Masini L, Catalano L, Fiacchini M, de Vivo A, Gozzetti A, Lazzaro A, Tura S, Baccarani M. Prospective, randomized study of single compared with double autologous stem-cell transplantation for multiple myeloma: Bologna 96 clinical study. J Clin Oncol 2007;25:2434-41.

8. Morris C, Iacobelli S, Brand R, Bjorkstrand B, Drake M, Niederwieser D, Gahrton G. Benefit and timing of second transplantations in multiple myeloma: clinical findings and methodological limitations in a European group for blood and marrow transplantation registry study. J Clin Oncol 2004;22:1674-81.

9. Bruno B, Rotta M, Patriarca F, Mordini N, Allione B, Carnevale-Schianca F, Giaccone L, Sorasio R, Omede P, Baldi H, Bringhen S, Massaia M, Aglietta M, Levis A, Gallamini A, Fanin R, Palumbo A, Storb R, Ciccone G, Boccadoro $\mathrm{M}$. A comparison of allografting with autografting for newly diagnosed myeloma. N Eng J Med 2007;356:1110-20.

10. Attal M, Harousseau JL, Leyvraz S, Doyen C, Hulin C, Benboubker L, Agha IY, Bourhis JH, Garderet L, Pegourie B, Dumontet C, Renaud M, Voillat L, Berthou C, Marit G, Monconduit M, Caillot D, Grobois B, Avet-Loiseau H, Moreau P, Facon T. Maintenance therapy with thalidomide improves survival in patients with multiple myeloma. Blood 2006;108:3289-94.

11. Abdelkefi A, Ladeb S, Torjman L, Ben Othman T, Lakhal A, Ben Romdhane N, El Omri H, Elloumi M, Belaaj H, Jeddi R, Aissaoui L, Ksouri H, Ben Hassen A, Msadek F, Saad A, Hsairi M, Boukef K, Amouri A, Louzir H, Dellagi K, Ben Abdeladhim A. Single autologous stem-cell transplantation followed by maintenance therapy with thalidomide is 
superior to double autologous transplantation in multiple myeloma: results of a multicenter randomized clinical trial. Blood 2008;111:1805-10.

12. Stadtmauer EA. Multiple myeloma, 2004-one or two transplants? N Eng J Med 2003;349:2551-3.

13. Fruehauf S, Klaus J, Huesing J, Veldwijk MR, Buss EC, Topaly J, Seeger T, Zeller LW, Moehler T, Ho AD, Goldschmidt $\mathrm{H}$. Efficient mobilization of peripheral blood stem cells following CAD chemotherapy and a single dose of pegylated G-CSF in patients with multiple myeloma. Bone Marrow Transplant 2007;39:743-50.

14. Badros A, Goloubeva O, Fenton R, Rapoport AP, Akpek G, Harris C, Ruehle K, Westphal S, Meisenberg B. Phase I trial of first-line bortezomib/thalidomide plus chemotherapy for induction and stem cell mobilization in patients with multiple myeloma. Clin Lymphoma Myeloma 2006;7:21-6.

15. Jacoub JF, Suryadevara U, Pereyra V, Colon D, Fontelonga A, MacKintosh FR, Hall SW, Ascensao JL. Mobilization strategies for the collection of peripheral blood progenitor cells: results from a pilot of delayed addition G-CSF following chemotherapy and review of the literature. Exp Hematol 2006;34:1443-50.

16. Koenigsmann M, Jentsch-Ullrich K, Mohren M, Becker E, Heim M, Franke A. The role of diagnosis in patients failing peripheral blood progenitor cell mobilization. Transfusion 2004;44:777-84.

17. Morris CL, Siegel E, Barlogie B, Cottler-Fox M, Lin P, Fassas A, Zangari M, Anaissie E, Tricot G. Mobilization of CD34+ cells in elderly patients ( $>70$ years) with multiple myeloma: influence of age, prior therapy, platelet count and mobilization regimen. Br J Haematol 2003;120:413-23.

18. de al Rubia J, Blade J, Lahuerta JJ, Ribera JM, Martinez R, Alegre A, Garcia-Larana J, Fernandez P, Sureda A, de Arriba F, Carrera D, Besalduch J, Boyera RG, Bernal LP, Hernandez MT, Garcia PR, Perez-Calvo J, Alcala A, Casado LF, Miguel JS. Effect of chemotherapy with alkylating agents on the yield of CD34+ cells in patients with multiple myeloma. Results of the Spanish Myeloma Group (GEM) Study. Haematologica 2006;92:621-7.

19. Alegre A, Tomas JF, Marinez-Chamorro C, Gil-Fernandez JJ, Fernandez-Villalta MJ, Arranz R, Diaz MA, Granda A, Bernardo MR, Escudero A, Lopez-Lorenzo JL, FernandezRanada JM. Comparison of peripheral blood progenitor cell mobilization in patients with multiple myeloma: highdose cyclophosphamide plus GM-CSF vs G-GSF alone. Bone Marrow Transplant 1997;20:211-7.

20. Hiwase DK, Bollard G, Hiwase S, Bailey M, Muirhead J, Schwarer AP. Intermediate-dose CY and G-CSF more efficiently mobilize adequate numbers of PBSC for tandem autologous PBSC transplantation compared with low-dose CY in patients with multiple myeloma. Cytotherapy 2007;9: 539-47.

21. Kroger N, Renges H, Kruger W, Gutensohn K, Loliger C, Carrero I, Cortes L, Zander AR. A randomized comparison of once versus twice daily recombinant human granulo- cyte colony-stimulating factor (filgrastim) for stem cell mobilization in healthy donors for allogeneic transplantation. Br J Haematol 2000;111:761-5.

22. Gojo I, Guo C, Sarkodee-Adoo C, Meisenberg B, Fassas A, Rapoport AP, Cottler-Fox M, Heyman M, Takebe N, Tricot G. High-dose cyclophosphamide with or without etoposide for mobilization of peripheral blood progenitor cells in patients with multiple myeloma: efficacy and toxicity. Bone Marrow Transplant 2004;34:69-76.

23. Zubair AC, Grant R, Wu W, Tun H, Rivera C, MorenoAspitia A, Joyce M, Roy V, Colon-Otero G, Solberg LA. Platelet count is a sensitive predictor of autologous peripheral blood progenitor cell collection yield in previously treated plasma cell disease patients. Transfusion 2008;48: 1106-14.

24. Yu J, Leisenring W, Bensinger WI, Holmberg LA, Rowley SD. The predictive value of white cell of CD34+ cell count in the peripheral blood for timing apheresis and maximizing yield. Transfusion 1999;39:442-50.

25. Ford CD, Chan KJ, Reilly WF, Petersen FB. An evaluation of predictive factors for CD34+ cell harvest yields from patients mobilized with chemotherapy and growth factors. Transfusion 2003;43:622-5.

26. Benjamin RJ, Linsley L, Fountain D, Churchill WH, Sieff C, Cannon ME, Uhl L, Gaynes L, Antin JH, Wheeler C. Preapheresis peripheral blood CD34+ mononuclear cell counts as predicators of progenitor cell yield. Transfusion 1997;37:79-85.

27. Moog R. Management strategies for poor peripheral blood stem cell mobilization. Transfus Apher Sci 2008;38: 229-36.

28. Dolan K, Blume C, Capone C, Cooling L, Champney D, Henry JB, Huebner P, Sisson S. Anatomic placement affects the performance of the Neostar Pheres-Flow Catheter [abstract]. J Clin Apher 2000;15:A69.

29. Lin JS, Burgstaler EA, Pineda AA, Gertz MA. Effects of whole blood flow rates on mononuclear cell yields during peripheral blood stem cell collection using Fenwal CS3000 Plus. J Clin Apher 1995;10:7-11.

30. Burgstaler JE, Pineda AA, Winter JL. Effects of high whole blood flow rates and high peripheral WBC on CD34+ yield and cross-cellular contamination [abstract]. Cytotherapy 2003;5:446.

31. Ford CD, Pace N, Lehman C. Factors affecting the efficiency of collection of CD34-positive peripheral blood cells by a blood cell separator. Transfusion 1998;38:1046-50.

32. Bellavita P, Celega E, Poma R. Comparison of performance of six different cell separators in collecting peripheral blood mononuclear cells. Transfus Sci 1997;18:215-21.

33. Dzieczkowski JS, McGonigal M, Cook J, Sugrue M, Andersen J, Anderson KC. A comparison of peripheral blood stem cell apheresis using the Fenwal CS3000 Plus and COBE Spectra. Transfus Sci 1995;16:71-7.

34. Berretta F, van den Bosch S, Castelli D, Cavalli F, Ghielmini M. Intrapatient comparison of an intermittent and a 
continuous flow cell separator for the collection of progenitor and stem cells from the blood. Vox Sang 1998;75: 149-53.

35. Ikeda K, Ohto H, Nemoto K, Yamamoto G, Kato K, Ogata T, Shichishima T, Maruyama Y. Collection of MNCs and progenitor cells by two separators for transplantation: a randomized crossover trial. Transfusion 2003;43: 814-9.

36. Mehta J, Powles R, Treleaven J, Millar B, Proctor H, Cabral S, Shephard V, Singhal S. Prospective, concurrent comparison of the Cobe Spectra and Haemonetics MCS-3P cell separators for leukapheresis after high-dose filgrastim in patients with hematologic malignancies. J Clin Apher 1997; 12:63-7.

37. Morton JA, Baker DP, Hutchins CJ, Durran ST. The COBE Spectra cell separator is more effective than the Haemonetics MCS-3P cell separator for peripheral blood progenitor cell harvest after mobilization with cyclophosphamide and filgrastim. Transfusion 1997;37:631-3.

38. Heuft HG, Dubiel M, Rick O, Kingreen D, Serke S, Schwella $\mathrm{N}$. Inverse relationship between patient peripheral blood CD34+ cell counts and collection efficiency for CD34 cells in two automated systems. Transfusion 2001;41:1008-13.

39. Wilke R, Brettell M, Prince HM, Wolf M, McKenna R, Serpell E, Molloy M, Stevens H, Quinn M, Gates P, Chapple P. Comparison of COBE® Spectra ${ }^{\mathrm{TM}}$ software version 4.7 PBSC and version 6.0 PBSC ${ }^{\text {TM }}$ program. J Clin Apher 1999; 14:26-30.

40. Schreiner T, Wiesneth M, Krug E, Kalinova J, Buchele H, Maccari B, Erne E, Bischof C, De Reys S. Collection of allogeneic peripheral blood progenitor cells by two protocols on an apheresis system. Transfusion 1998;38:1051-5.

41. Ravagnani F, Siena S, De Reys S, Di Nicola M, Notti P, Giardini R, Bregni M, Matteucci P, Gianni AM, Pellegris G. Improved collection of mobilized CD34+ hematopoietic progenitor cells by a novel automated system. Transfusion 1999;39:48-55.

42. Rowley SD, Prather K, Bui KT, Appel M, Felt T, Bensinger WI. Collection of peripheral blood progenitor cells with an automated leukapheresis system. Transfusion 1999;39: 1200-6.

43. Green RH, Watson D, Buchanan S, Morrison AE. A prospective randomized concurrent comparison of the COBE Spectra Version 4.7, COBE Spectra Version 6 (AutoPBSC ${ }^{\text {TM})}$ and Haemonetics MCS+ cell separators for leucapheresis in patients with haematological and non-haematological malignancies. Transfus Sci 2001;24:85-90.

44. Adorno G, Del Proposto G, Palombi F, Bruno A, Ballatore G, Postorino M, Tendas A, Del Poeta G, Isacchi G, Amadori S. Collection of peripheral progenitor cells: a comparison between Amicus and Cobe-Spectra blood cell separators. Transfus Apher Sci 2004;30:131-6.

45. Lee CK, Barlogie B, Munshi N, Zangari M, Fassas A, Jacobson J, van Rhee F, Cottler-Fox M, Muwalla F, Tricot G. DTPACE: an effective, novel combination chemotherapy with thalidomide for previously treated patients with myeloma. J Clin Oncol 2003;21:2732-9.

46. Shah-Khan F, Cooling L, Hoffmann S, Mineishi S, Herrst $\mathrm{M}$, Davenport R. DT-PACE is equivalent or superior to cytoxan+G-CSF or G-CSF alone for the collection of CD34 cells in multiple myeloma [abstract]. Transfusion 2008;48 Suppl:126A.

47. Hoffmann S, Zhou L, Gu Y, Davenport R, Cooling L. Delayed platelet engraftment in group $\mathrm{O}$ patients after autologous progenitor cell transplantation. Transfusion 2005;45:885-95.

48. Bolan CD, Cecco SA, Wesley RA, Horne M, Yau YY, Remaley AT, Childs RW, Barrett AJ, Rehak NN, Leitman SF. Controlled study of citrate effects and response to IV calcium administration during allogeneic peripheral blood progenitor cell donation. Transfusion 2002;42: 935-46.

49. Sutherland DR, Anderson L, Keeney M, Nayar M, Chin-Yee R. The ISHAGE guidelines for CD34+ cell determination by flow cytometry. International Society for Hematotherapy and Graft Engineering. J Hematother 1996;5:213-26.

50. Lacey M. Summaries of topics: inference in linear regression. Yale University Department of Statistics, Introduction to Statistics 101-103, 1997-98. [cited 2009 June]. Available from: http://www.stat.yale.edu/Courses/1997-98/101/ linregin.htm

51. Gidron A, Verma A, Doyle M, Boggio L, Evens A, Gordon L, Singhal S, Tallman M, Williams S, Winter J, Mehta J. Can the stem cell mobilization technique influence CD34+ cell collection efficiency of procedures in patients with hematologic malignancies? Bone Marrow Transplant 2005;35: 243-6.

52. Leblond PF. Hemorheology and blood diseases. In: Chien S, Dormandy J, Ernst E, Matrai A, editors. Clinical hemorheology. Dordrecht (The Netherlands): Marinuse Nijhoff Publishers; 1987. p. 227-49.

53. Micallef IN, Apostolidis J, Rohatiner AZ, Wiggins C, Crawley CR, Foran JM, Leonhardt M, Bradburn M, Okukenu E, Salam A, Matthews J, Cavenagh JD, Gupta RK, Lister TA. Factors which predict unsuccessful mobilization of peripheral blood progenitor cells following G-CSF alone in patients with non-Hodgkin's lymphoma. Hematol J 2000;1:367-73.

54. Kuittinen T, Nousiainen T, Halonen P, Mahlamaki E, Jantunen E. Prediction of mobilisation failure in patients with non-Hodgkin's lymphoma. Bone Marrow Transplant 2004; 33:907-12.

55. Hill L, Ratliff B, Richman C, Fernando LP. Comparison of two methods for peripheral blood stem cell collection in adult patients using the COBE Spectra ${ }^{\mathrm{TM}}$. J Clin Apher 2008;23:A43.

56. Perseghin P, Dassi M, Balduzzi A, Rovelli A, Bonanomi S, Uderzo C. Mononuclear cell collection in patients undergoing extra-corporeal photo-chemotherapy for acute and chronic graft-vs.-host disease (GvHD): comparison 
between COBE Spectra Version 4.7 and 6.0 (AutoPBSC). J Clin Apher 2002;17:65-71

57. Cooling L, Gorlin JB. Transfusion reactions associated with hematopoietic progenitor cell reinfusion. In: Popovsky MA, editor. Transfusion reactions. 3rd ed. Bethseda: AABB Press; 2007. p. 302-22.

58. Zambelli A, Poggi G, da Prada GA, Pedrazzoli P, Cuomo A, Miotti D, Perotti C, Preti P, Robustelli della Cuna G. Clinical toxicity of cryopreserved circulating progenitor cells infusion. Cancer Res 1998;18:4705-8.

59. Calmels B, Lemarie C, Esterni B, Malugani C, Charbonnier A, Coso D, Shiaono de Colella JM, Deconinck E, Caillot D, Viret F, Ladaique P, Lapierre V, Chabannon C. Occurrence and severity of adverse events after autologous hematopoietic progenitor cell infusion are related to the amount of granulocytes in the apheresis product. Transfusion 2007; 47:1268-75.

60. Richa E, Bryant S, Greiner C, Gastineau D. Correlation between the amount of infused granulocytes and side effects of stem cells infusion [abstract]. Transfusion 2008;48 Suppl:126A.

61. Mahe B, Milpied N, Hermouet S, Robillard N, Moreau P, Letortorec S, Rapp MJ, Bataille R, Harousseau JL. G-CSF alone mobilizes sufficient peripheral blood CD34+ cells for positive selection in newly diagnosed patients with myeloma. Br J Haematol 1996;92:263-8.

62. Kroger N, Zeller W, Fehse N, Hassan HT, Kruger W, Gutensohn K, Lolliger C, Zander AR. Mobilizing peripheral blood stem cells with high dose G-CSF alone is as effective as with Dexa-BEAM plus G-CSF in lymphoma patients. Br J Haematol 1998;102:1101-6.

63. D’Hondi L, Emmons RV, Andre M, Guillaume T, Feyens AM, Canon JL, Humblet Y, Longueville J, Symann M. The administration of $10 \mu \mathrm{g} / \mathrm{kg}$ granulocyte-colony-stimulating factor (G-CSF) alone results in a successful peripheral blood stem cell collection when previous mobilization with chemotherapy and hematopoietic growth factor failed. Leuk Lymphoma 1999;34:105-9.

64. Kuroiwa M, Okamura T, Kanaji T, Okamura S, Harada M, Niho Y. Effects of granulocyte colony-stimulating factor on the hemostatic system in healthy volunteers. Int J Hematol 1996;63:311-6.

65. Nomura S, Inami N, Kanazawa S, Iwasaka T, Fukuhara S. Elevation of platelet activation markers and chemokines during peripheral blood stem cell harvest with G-CSF. Stem Cells 2004;22:696-703.

66. Topcuoglu P, Arat M, Dalva K, Ozcan M. Administration of granulocyte-colony-stimulating factor for allogeneic hematopoietic cell collection may induce the tissue factordependent pathway in healthy donors. Bone Marrow Transplant 2004;33:171-6.

67. Burgstaler EA, Mako A, Winters JL. Use of manual color monitoring to enhance hematopoietic progenitor cell collection on Fenwal Amicus [abstract]. J Clin Apher 2008; 23:A44. 